\title{
A REASSESSMENT OF BUNODONT METATHERIANS FROM THE PALEOGENE OF ITABORAÍ (BRAZIL): SYSTEMATICS AND AGE OF THE ITABORAIAN SALMA
}

\author{
ÉDISON V. OLIVEIRA \\ Laboratório de Paleontologia, Departamento de Geologia, CTG, UFPE, Av. Acadêmico Hélio Ramos s/n, 50740-530, Recife, \\ PE, Brazil.vicenteedi@gmail.com \\ FRANCISCO J. GOIN \\ División Paleontología Vertebrados, Museo de La Plata, CONICET, Paseo del Bosque s/n, B1900FWA La Plata, Buenos \\ Aires Province, Argentina. fgoin@fcnym.unlp.edu.ar
}

\begin{abstract}
Early Paleogene metatherians with inflated, low cusps (bunodont dentition), such as Bobbschaefferia, Procaroloameghinia, Protodidelphis, Guggenheimia, and Zeusdelphys have been subject to different interpretations regarding their affinities. A phylogenetic study including these bunodont marsupials and other selected metatherians presented here leads to the recognition of the following taxonomic assignments: “Ameridelphia”, Protodidelphidae: Carolocoutoia ferigoloi, Guggenheimia brasiliensis, G. crocheti sp. nov., Protodidelphis vanzolinii, P. mastodontoides (=Robertbutleria mastodontoidea), Periprotodidelphis bergqvisti gen. et sp. nov., and Zeusdelphys complicatus; Marsupialia, Didelphimorphia, Peradectoidea, Caroloameghiniidae: Procaroloameghinia pricei; Australidelphia, Polydolopimorphia, family indet.: Bobbschaefferia fluminensis and aff. Bobbschaefferia sp.. The phylogenetic analysis does not support a closer relationship between protodidelphids and living didelphids as well as between Guggenheimia and Mirandatherium. No closer relationship was found between Zeusdelphys with Minusculodelphis and Monodelphopsis. Procaroloameghinia is regarded as a peradectoid didelphimorphian with bunoid dentition convergent with, but without direct affinities to, protodidelphids or polydolopimorphians. Bobbschaefferia is regarded as a basal polydolopimorphian, even though the scarce evidence at hand prevents us from assign it to any particular family of the suborder Hatcheriformes. Correlation with stratigraphic, sedimentary and magmatic data from some of the best studied margin basins in SE Brazil, together with the systematic reassessment of bunodont metatherians from Itaboraí, suggest that the Itaboraian SALMA is latest Paleoceneearly Eocene in age. Itaboraian protodidelphids, sternbergiids and caroloameghiniids are also recorded in the Las Flores locality/ Formation (central Patagonia) and in the La Barda locality (northwestern Patagonia) during the latest Paleocene and early Eocene.
\end{abstract}

Key words: Metatheria, “Ameridelphia”, Australidelphia, Didelphimorphia, Eocene, chronostratigraphy.

RESUMO - Metatérios do Paleógeno inicial com cúspides infladas e baixas (bunodontes) como Bobbschaefferia, Procaroloameghinia, Protodidelphis, Guggenheimia e Zeusdelphys têm sido objeto de diferentes interpretações sobre suas afinidades. Um estudo filogenético, incluindo esses marsupiais bunodontes, assim como outros metatérios selecionados, conduz ao reconhecimento das seguintes atribuições taxonômicas: "Ameridelphia", Protodidelphidae: Carolocoutoia ferigoloi, Guggenheimia brasiliensis, G. crocheti sp. nov., Protodidelphis vanzolinii, P. mastodontoides (= Robertbutleria mastodontoidea), Periprotodidelphis bergqvisti gen. et sp. nov. e Zeusdelphys complicatus; Marsupialia, Didelphimorphia, Peradectoidea, Caroloameghiniidae: Procaroloameghinia pricei; Australidelphia, Polydolopimorphia, fam. indet.: Bobbschaefferia fluminensis and aff. Bobbschaefferia sp.. A análise filogenética não fornece suporte a uma íntima relação entre protodidelfídeos e didelfídeos viventes. Nenhuma relação próxima foi encontrada entre Zeusdelphys com Minusculodelphis e Monodelphopsis. Procaroloameghinia é posicionado como um didelfimórfio basal (Peradectoidea, Caroloameghiniidae), com dentição bunodonte convergente, porém sem afinidade direta a protodidelfídeos e polidolopimórfios. Bobbschaefferia é considerado como um polidolopimórfio basal, embora sua escassa evidência impossibilite atribuí-lo a qualquer família em particular da subordem Hatcheriformes. Correlação com dados estratigráficos, sedimentares e magmáticos de algumas bacias marginais bem estudadas do sudeste do Brasil, juntamente com a revisão sistemática de metatérios bunodontes de Itaboraí, sugere que a SALMA Itaboraiense é de idade Paleoceno tardioEoceno inicial. Protodidelfídeos, sternbergídeos e caroloameghinídeos itaboraienses são também reportados na localidade/Formação Las Flores (Patagonia central) e na localidade La Barda (NE Patagonia) durante o Paleoceno tardio e o Eoceno inicial.

Palavras-chave: Metatheria, “Ameridelphia”, Australidelphia, Didelphimorphia, Eoceno, cronoestratigrafia.

\section{INTRODUCTION}

After Simpson's (1945) influential classification, Ride's study of the phylogenetic affinities of southern metatherians proposed a larger ordinal diversity for fossil and living forms (Ride, 1964). For instance, he ressurected Ameghino's (1894) Paucituberculata for the inclusion of "pseudodiprotodont" South American marsupials. Since then, numerous 
phylogenetic studies dealing with basal, Paleogene "opossum-like" taxa have been produced in the last decades (e.g. Szalay, 1982, 1994; Archer, 1984; Aplin \& Archer, 1987; Reig et al., 1987; Marshall et al., 1990; Rougier et al., 1998; Goin \& Candela, 2004; Case et al., 2005; Sánchez-Villagra et al., 2007; Goin et al., 2010; Horovitz et al., 2009; Ladevèze \& Muizon, 2010). Our knowledge of South American Paleogene metatherians has notably increased in the last years, mainly due to the discoveries of new faunas, but also because of the restudy of those taxa already known (e.g. Muizon, 1991; Crochet \& Sigé, 1993; Goin et al., 1997, 1998a; Goin \& Candela, 2004; Oliveira, 1998; Sigé et al., 2009; Tejedor et al., 2009).

Metatherians included in the present study are part of the most diverse association known up to now from the Paleogene of South America. They were recovered from fissure fillings in the travertine limestones of the Itaboraí Basin, located at São José district, Itaboraí, State of Rio de Janeiro, Brazil (Figure 1). Fossils of gastropods were first discovered at this locality during the early 1930's. In 1944 the first mammals were recovered and later described by Price $\&$ Paula Couto (1946). The study of the fossil metatherians from Itaboraí, including the description of new genera and species, began with Simpson (1947), and was continued by Paula Couto (1952a-c). Further studies by Paula Couto $(1961,1962,1970)$ increased knowledge of this metaherian fauna. In subsequent papers (Marshall, 1981, 1982a,b, 1987) reviewed several

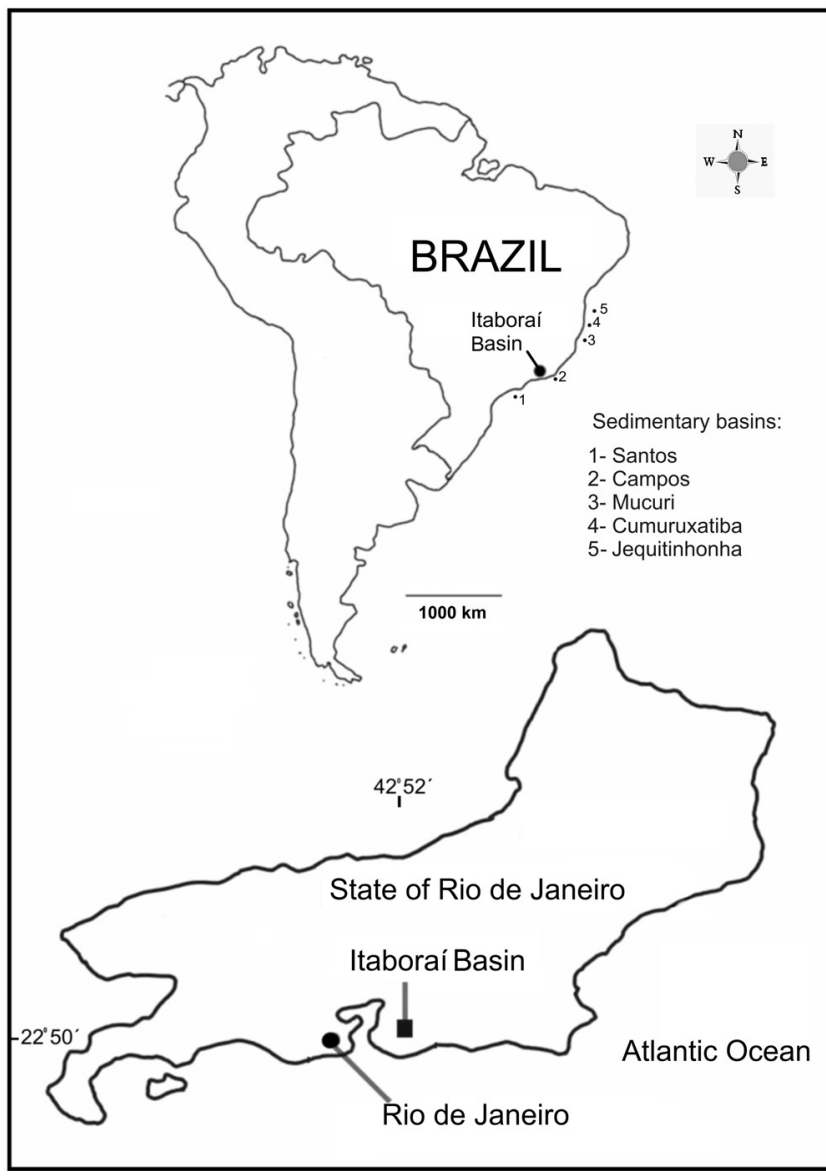

Figure 1. Location map detailing the region of the Itaboraí Basin. metatherian taxa from the Itaboraí locality. Discoveries of new specimens, reassessments of some already known taxa, and descriptions of new metatherians were presented by Marshall \& Muizon (1984), Muizon \& Brito (1993), Oliveira (1998, 1999), Goin et al. (1998a, 2009), Oliveira \& Goin (2006), and Goin \& Oliveira (2007). The study by Marshall (1987) still constitutes a reference for the knowledge of living and extinct lineages of South American metatherians. Important studies describing postcranial and petrosal metatherians from Itaboraí were presented by Szalay \& Sargis (2001), Ladevèze $(2004,2007)$ and Ladevèze \& Muizon (2010).

Several bunodont taxa described from the Itaboraí fauna have been subject of different interpretations regarding their affinities, even extending to the ordinal level (Goin, 2003; Oliveira \& Goin, 2003; Ladevèze \& Muizon, 2010). These bunodont taxa have teeth with low, inflated cusps, probably related with an omnivorous diet or, in some cases, to frugivory (see Lucas, 2004). They include several genera currently referred to Protodidelphidae, as well as several others (e.g. Bobbschaefferia, Procaroloameghinia, and Zeusdelphys) which sometimes were interpreted as closely related with, or placed in, Protodidelphidae (Marshall et al., 1990). Other bunodont marsupials from Itaboraí such as Epidolops, Gasthernia and Mirandatherium are far more distantly related, and will be restudied in future contributions.

The taxonomic history of bunodont metatherians from Itaboraí began in 1952 when Carlos de Paula Couto described dental remains of one of the largest "opossum-like" metatherian from this locality, which was named Protodidelphis vanzolinii and classified within the family Didelphidae (Paula Couto, 1952a-c). This family, as generally understood, is probably a wastebasket taxon that includes a series of taxa of still uncertain affinities (Aplin \& Archer, 1987; Oliveira, 1998; Goin, 2003), but Voss \& Jansa (2009) restrict Didelphidae to crown-group Didelphimorphia. A preliminary revision of bunodont marsupials from Itaboraí (Goin et al., 1998a) led to the description of the largest known (fossil or living) "didelphimorphian", Carolocoutoia ferigoloi, which was placed (with Protodidelphis, Guggenheimia, and "Robertbutleria") within Protodidelphidae, which in turn was regarded as an early lineage of "Didelphimorphia".

Compared to other Paleogene South American mammalian associations, the Itaboraian association constitutes not only the most diverse but also the most eastern, tropical (i.e. northern) South American Paleogene mammalian record known up to date. This geographic position in relation to more southern sites is relevant concerning the biogeographical relationships between South American and African, European, Asian and North American marsupials (Oliveira \& Goin, 2006).

The Itaboraí mammalian association represents the type fauna of the Itaboraian SALMA (South American Land Mammal Age), originally interpreted as medial Paleocene (Marshall, 1985). Notwithstanding, new evidence and the reevaluation of some published data have led to a revision of the original concept, and the fauna has been considered as medial to late Paleocene (Oliveira, 1998; Medeiros \& 
Bergqvist, 1999) or latest Paleocene-early Eocene (Marshall et al., 1997; Gelfo et al., 2009). Some of the difficulties in estimating an age for Itaboraí stem from correlation with some problematical faunas of Patagonia such as those from the Riochican, misinterpretation of available radiometric ages for Itaboraí and the absence of correlative studies with the contemporary Paleogene Brazilian margin basins. This paper presents a review and an update of the bunodont metatherians from Itaboraí. We restudy the already known type and referred materials, as well as new, unpublished specimens from the Museu de Ciências da Terra and Museu Nacional (both in Rio de Janeiro) and the Museu de Ciências Naturais da Fundação Zoobotânica do Rio Grande do Sul (in Porto Alegre), Brazil. This last step led us to recognize several new taxa, including a new species of Guggenheimia and a new genus and species of Protodidelphidae. Additionally, we reassess the age of Itaboraí SALMA on the basis of available data, including radiometric dates, faunal correlation, and stratigraphic, sedimentary and magmatic data from the Brazilian Paleogene margin basins. Finally, we briefly discuss the biogeographic significance of the Itaboraí metatherian association in relation to other metatherian faunas from South America and from other continents as well.

Institutional abbreviations. MCT (ex DGM), Museu de Ciências da Terra, Rio de Janeiro, Brazil; MCN-PV, Seção de Paleontologia, Museu de Ciências Naturais da Fundação Zoobotânica do Rio Grande do Sul, Porto Alegre, RS, Brazil; MNRJ, Museu Nacional do Rio de Janeiro, Rio de Janeiro, RJ, Brazil. MLP, Museo de La Plata, La Plata, Buenos Aires, Argentina.

Other abbreviations. SALMA, South American Land Mammal Age; i2, i3, i4, i5, lower incisors (Hershkovitz, 1995); p1, p2, p3, lower premolars; m1, m2, m3, m4, lower molars; M1, M2, M3, M4, upper molars; StA, StB, StC, StD, StE, stylar cusps A, B, C, D, E respectively; L, anteroposterior length; W, labiolingual width; *, approximate measurement. Molar cusp and crest nomenclature and terminology are illustrated in Figure 2 and follow Oliveira \& Goin (2006) and Goin \& Candela (2004). All measurements are in millimeters.

\section{GEOLOGY AND AGE OF THE ITABORAIAN SALMA}

\section{Geology of the Itaboraí Basin}

The Itaboraí Basin is the oldest and smallest basin of the Continental Rift of Southeastern Brazil (Medeiros \& Bergqvist, 1999). The basin is a small half-graben, $1.5 \mathrm{~km}$ long and $0.5 \mathrm{~km}$ wide, in the eastern part of the Continental Rift of Southeastern Brazil (CRSB) (Riccomini, 1989; Riccomini et al., 1996). The rift, Cenozoic in age, has an ENE-trending, narrow, elongate trough, approximately $1000 \mathrm{~km}$ long that stretches from Curitiba (Parana State) in the WSW to Barra de São João (Rio de Janeiro State) in the ENE. Paleogene mammal-bearing units from CRSB in southeastern Brazil include the Itaboraí and Taubaté basins.

The sediments that filled the Itaboraí Basin are grouped in three sequences: the lower sequence (S1) is basically composed of interbedded clastic and chemical carbonates (travertine limestone) that originate from debris flows in a tectonic lake. The sporadic occurrence of carbonatic shales and lignites is recorded in this sequence (Ferrari, 2001). According to Medeiros \& Bergqvist (1999) the oolitic-pisolitic limestone facies occurs in association with the travertine limestone and is composed of grains of $1 \mathrm{~mm}$ to $10 \mathrm{~mm}$, usually with an ellipsoidal shape, and with a nucleus constituted by mineral grains or, very rarely, by small gastropods. The gray limestone is an association of facies which grades laterally from calcirudites, calcarenites into sandy and silty limestones. The bedding is usually massive; however, normal or inverse grading occurs locally. This association of facies is intercalated with the travertine limestone and forms the floor of the basin (Medeiros \& Bergqvist, 1999). From this sequence gastropods are abundant, while woods, reptiles and mammals are scarce. The middle sequence (S2) comprises fissure filling deposits with marls and collapsed breccias whose composition is similar to the gray limestone facies, although poorly consolidated, and transported into these cavities by heavy rains and gravitational flows (Bergqvist et al., 2008). From
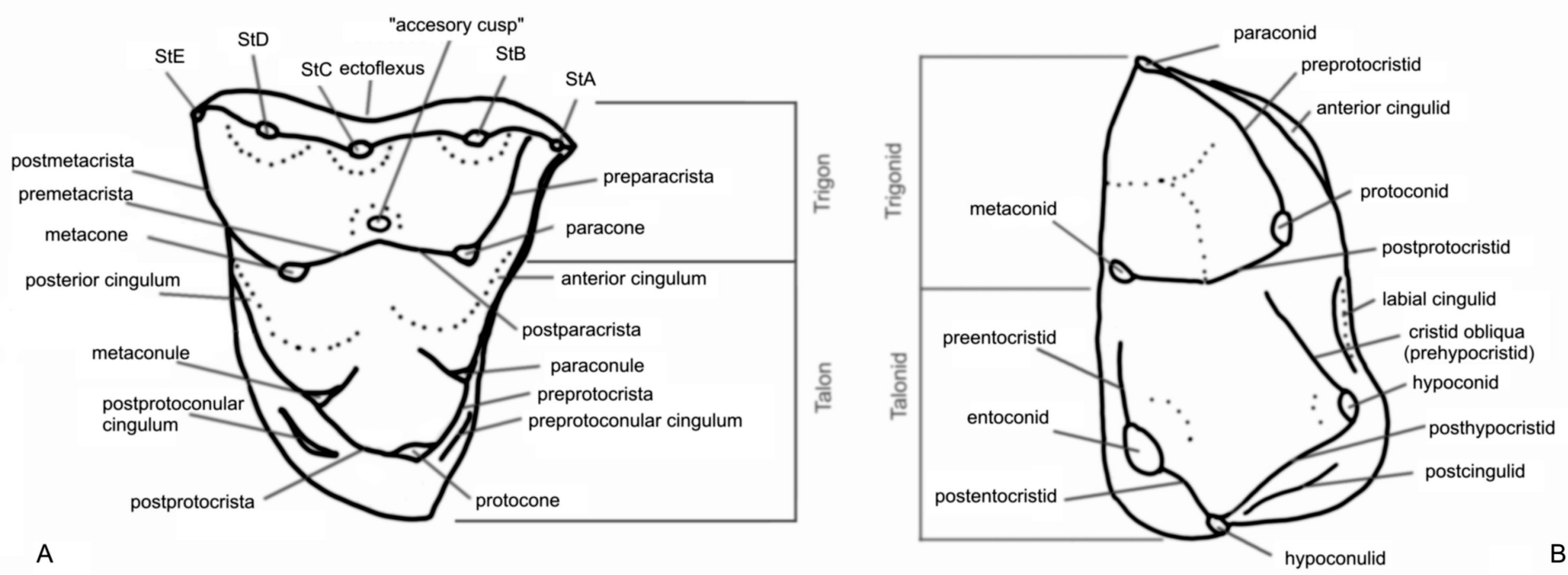

A

Figure 2. Dental terminology utilized as exemplified by an upper (A) and lower molar (B). 
these limestones were recovered abundant fossil vertebrates, most of them mammals (Bergqvist et al., 2008). The upper sequence (S3) is composed of siliciclastic rocks (mudstones, sandstones, and conglomerates) derived from gneissic source areas around the basin. They were deposited by subaerial mudflows in an alluvial fan system (Tibana et al., 1984; Sant'Anna, 1999) and interdigitate with and overlie the carbonate sequence with sharp contacts. Sant'Anna (1999) correlated the conglomerate mudstones of Itaboraí with similar sediments occurring in the Resende Formation, which is Eocene-Oligocene in age.

\section{Tectonic, magmatic and sedimentary evidences of early Paleogene margin basins}

Although the Itaboraí Basin does not constitute a margin basin (see above) it is geographically close to margin basins and incorporates a magmatic event widely represented in several contemporary early Paleogene Brazilian basins. The available data for correlation include stratigraphic studies on the Brazilian Cenozoic margin basins made during more than 50 years of cumulative exploratory work by Petrobras, which allowed a firm understanding of the stratigraphy of these areas (see Milani et al., 2007). The Paleocene-Eocene data also include numerous $\mathrm{K}$-Ar datings that are here utilized for correlation.

According to Cordani (1970) and Thomaz-Filho et al. (2005) the Cabo Frio (Rio de Janeiro State) and Arquipélago de Abrolhos (Espirito Santo State) platforms constitute remarkable records of Eocene magmatism, which have been dated by the K-Ar method (Mizusaki \& Mohriak, 1992; Misuzaki et al., 1998, 2002). In the marine portion of the Espí- rito Santo, Mucuri and Cumuruxatiba basins, Mizusaki et al. (1994) identified igneo-basic rocks, volcanoclastic rocks, and interlayered sediments, coincident with the major volcanic event recognized in the Complexo de Abrolhos and surrounding areas. For example in the Mucuri Basin, in southern Bahia State, the E-30 and E-50 sequences represent the late Paleocene to late Eocene span documented by the large interlayered Abrolhos magmatic event, dated by K/Ar ages to between 37 to $59 \mathrm{My}$. An erosional surface present there was correlated with a 55 My sea-level lowstand, thus representing the Paleocene-Eocene transition (França et al., 2007). This very important Paleocene-Eocene erosional event (Figure 3), including associated magmatism, is also recorded in other sedimentary sequences of Brazilian marginal basins such as Pelotas, Santos, Campos, Espírito Santo, Cumuruxatiba, Jequitinhonha and Mucuri (Thomaz-Filho et al., 2005; Milani et al., 2007).

\section{Radiometric and palynological data}

Important chronological information relevant to the correlation of several taphrogenic basins of southeastern Brazil was obtained through radiometric dates on ankaramitic lava flows intercalated in these basins. In the non-marine basins, dates are available for Itaboraí and Volta Redonda (Almeida et al., 1996). Mizusaki et al. (1998) presented 377 K/ Ar radiometric dates of basic and alkaline magmatic rocks related to the rifting between South America and Africa, of which the major incidences of alkaline magmatic activity (produced by the break-up between South America and Africa) are from around $50 \mathrm{My}$ (early Eocene) and $10 \mathrm{My}$ (Miocene). Riccomini \& Rodrigues-Francisco (1992) dated

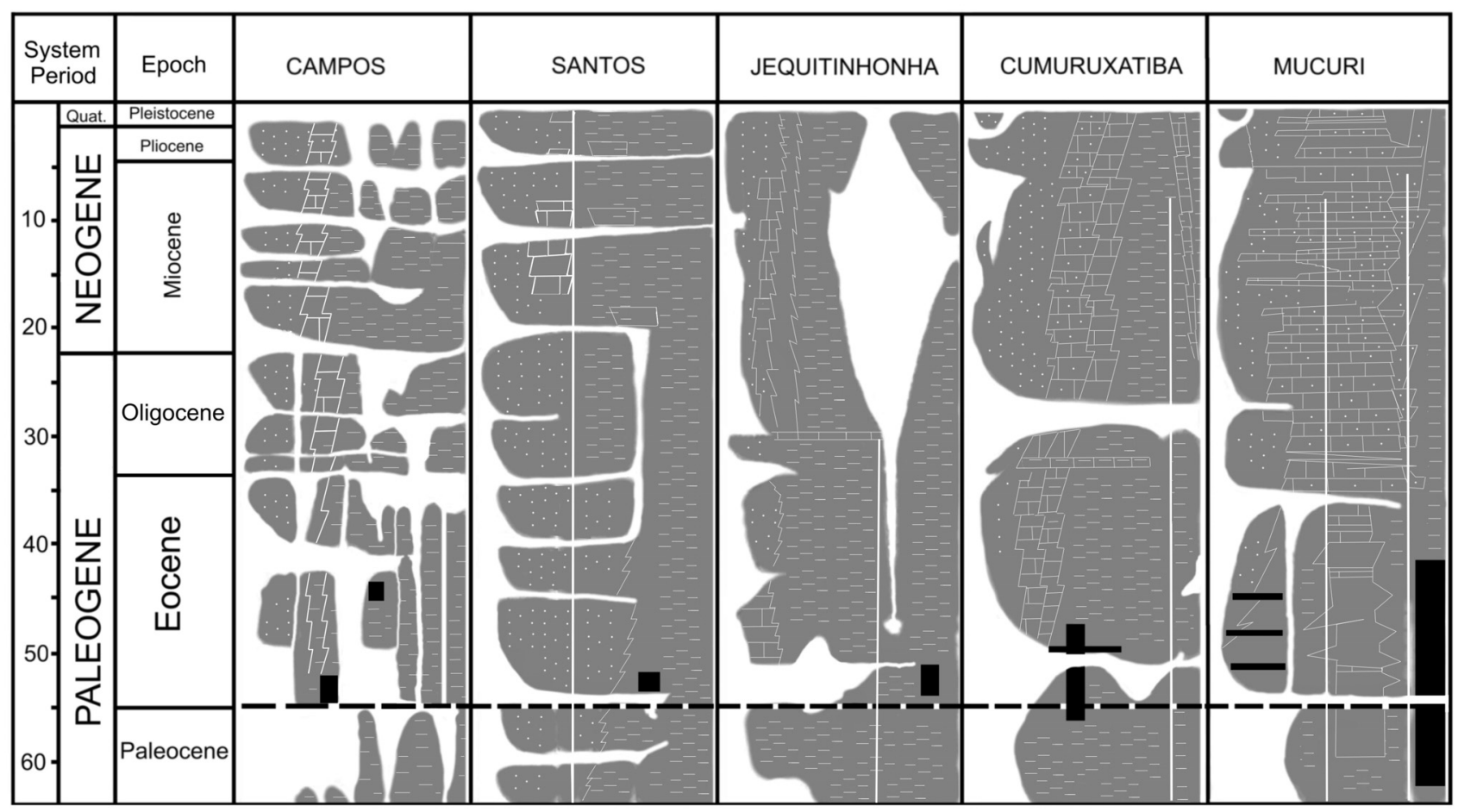

Figure 3. Stratigraphic charts of some Brazilian Cenozoic transform margin basins showing the magmatism (in bold) and erosional surface in the latest Paleocene-earliest Eocen (modified from Milani et al., 2007). 
the ankaramite of the Volta Redonda Basin as middle Eocene (43.8 \pm 6.2 and $41.7 \pm 5.7 \mathrm{My}$ ), and that from Itaboraí as early Eocene (52.6 $\pm 2.4 \mathrm{My})$. In Itaboraí the ankaramite flow occurs on the northern border, over the sequences $\mathrm{S} 1 / \mathrm{S} 2$. These data can be correlated with the widely recorded Eocene magmatic event (e.g. Abrolhos) between 37 and $59 \mathrm{My}$ reported by Misuzaki et al. (1998) in several Brazilian margin basins.

Another very important source of data is palynological analysis of a coal-bearing horizon (lignite) interlayered with alluvial fan deposits at the northern border of the Itaboraí Basin, which recorded the taxa Foveotriletes margaritae, Echitricolpites polaris, and Verrutriporites lunduensis (Macedo, 1975; Lima \& Souza-Cunha, 1986), suggesting a Paleocene-Eocene age (Lima \& Souza-Cunha, 1986).

\section{Mammal correlation}

The correlation of the Itaboraí fauna based on the stage of evolution with poorly calibrated SALMAs such as the Riochican is probably the main cause for the discrepant ages up to now inferred for the Itaboraian SALMA. Uncertainty regarding the ages of the San Jorge Basin mammal-bearing levels in Patagonia led previous studies to infer a medial to late Paleocene age for the Itaboraian SALMA, or even to disregard the Itaboraian as a SALMA (see Marshall, 1985; Marshall et al., 1987). Thus, correlation with the Riochican SALMA is inconclusive. New studies of Paleogene mammals from Patagonia have permitted a better picture of the early Eocene mammalian faunas and raise doubts on the age of the problematical Riochican SALMA (Tejedor et al., 2009). The latter was traditionally regarded as late Paleocene, about 55 My by Pascual \& Ortiz-Jaureguizar (1991). The two localities from the Eocene of central-western Patagonia are part of a possible new SALMA that fills the late early Eocene, between the Riochican and Casamayoran SALMAs (Tejedor et al., 2009).

Reviews by Oliveira (1998) and Oliveira \& Goin (2003) of the metatherians from Itaboraí led to the recognition of a new taxonomic arrangement, which has led to new hypotheses regarding the affinities of Patagonian and transatlantic methaterians (see Phylogenetic Analysis and Appendix 1). On the basis of metatherians and ungulates the Itaboraí assemblage can be correlated with Patagonian Paleogene mammalian faunas such as Las Flores, in Gran Barranca (central Patagonia). Another Paleogene association, that of Paso del Sapo (Goin et al., 1997; Tejedor et al., 2009), seems to be related to Las Flores, though younger in age.

The mammalian fauna of the Las Flores locality, on the eastern slopes of the Southern Cliff of Colhue Huapi Lake (Sarmiento Department, Chubut Province, Argentina), was originally correlated with the Banco Negro Inferior levels (Marshall et al., 1981). Later, it was referred to the Río Chico Group (Legarreta \& Uliana, 1994) and to the Kibenikhoria faunal zone (Bond et al., 1995). The Las Flores fauna includes several genera described originally from the Itaboraí locality, including metatherians such as Procaroloameghinia, Mirandatherium, Bobbschaefferia, Epidolops, Gashternia, Derorhynchus, Guggenheimia,
Protodidelphis, Carolopaulacoutoia, Marmosopsis, Didelphopsis, and Monodelphopsis, and ungulates such as Ernestokokenia, Asmithwoodwardia, Victorlemoinea, Henricosbornia, Itaboraitherium, Colbertia and Camargomendesia. Thus, these mammals show substantial identity with those of Itaborai at the generic level, suggesting a strong temporal correlation between the Itaboraí and Las Flores mammalian bearing-beds (Goin et al., 1997; Oliveira \& Goin, 2006).

Recent data from the early (but not earliest) Eocene mammalian fauna from western Patagonia (Paso del Sapo) obtained by Tejedor et al. (2009) provide new information that can be used in attempts to correlate Itaboraí with the Patagonian Paleogene mammalian-bearing units. A correlation between the Paso del Sapo and Itaboraí faunas is suggested by several mammalian genera, including the xenarthran Riostegotherium, metatherians such as cf. Itaboraidelphys, Marmosopsis, Protodidelphis, Derorynchus, and polydolopimorphians as Gashternia, as well as ungulates such as Asmithwoodwardia, and ?Victorlemoinea. However, several of the Patagonian mammal species are slightly more derived than their Itaboraian counterparts, suggesting that the latter are older. Based on radiometric dating of rocks overlying and underlying the mammal-bearing levels, Tejedor et al. (2009) concluded that the best estimate for the time span of the Paso del Sapo fauna is between 49.5 My and 45 My. They also state that the Paso del Sapo fauna may represent a new biochronological unit for the Paleogene of South America, one that also includes the La Meseta fauna of Antarctica (but see MacPhee \& Reguero, 2010).

Oliveira $(1998,1999)$ and Oliveira \& Goin $(2006)$ took into account the evolutionary stage of some Itaboraian marsupials (e.g. Derorhyncus, Carolopaulacoutoia) and suggested a strong transatlantic similarity with early Eocene Belgian, Portuguese and Turkish marsupials described by Crochet (1980), Estravis-Fernandez (1992) and Maas et al. (1998).

Another interesting calibration date inferred in previous works on Itaboraí age is that of Marshall et al. (1997), who suggested that the lacustrine limestones of Itaboraí was coeval with sea-level highstands, and the karst and the mammal-bearing infilling of its cavities with a major sea-level lowstand between 58.5 and $56.6 \mathrm{My}$, i.e. during the late Paleocene. However, as suggested by the ankaramite date, palynological data from lignite, stratigraphic data from Brazilian margin basins and faunal correlation with Patagonian successions, the Itaboraí fauna (which is mainly from the $\mathrm{S} 2$ sequence) could be coeval with periods of marine lowstands recorded during the latest Paleocene or earliest Eocene. According to Hardenbol et al. (1998), three important sea-level lowstands are verified for this time span, which correlates to C24 (Figure 4). The major pulses of sea-level lowering which could be utilized for calibration of the Itaboraian SALMA are recorded between about 55 and 49 My, representing the latest Paleocene-early Eocene span.

Finally, a conflict in the present latest Paleocene-early Eocene age assignment for Itaboraí fauna is that it overlaps the problematical Riochican SALMA. In this respect, the 


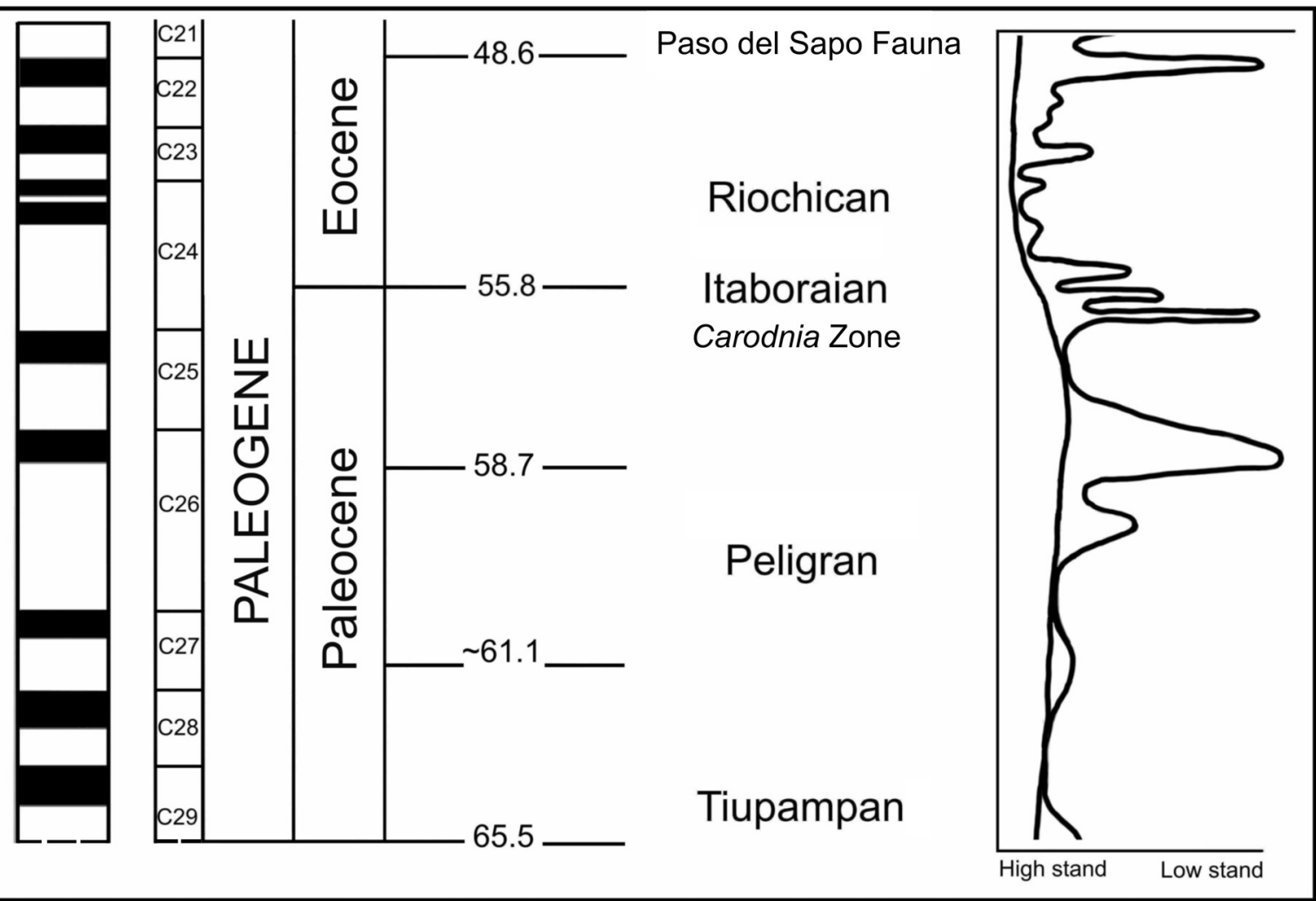

Figure 4. Early Paleogene fossil mammal chronology of South America, illustrating the approximate time frames for the Paleocene and Eocene SALMAs. The eustatic curve is of Hardenbol et al. (1998).

concept of a late Paleocene age for the Riochican by Simpson (1935) was tentative, but was subsequently followed in successive papers such as Paula Couto (1952a,b), Pascual \& Ortiz-Jaureguizar (1991) and Marshall et al. (1981, 1997). Pascual \& Ortiz Jaureguizar (1991) suggested for the Riochican a tentative age between 58.5 and $55 \mathrm{My}$ and from a taxonomic point of view the Riochican SALMA is defined by notoungulates replacing marsupials as the dominant mammals. Interestingly, the cluster analysis using Paleogene mammals grouped the Paso del Sapo and Riochican (Tejedor et al., 2009) suggesting that the Riochican SALMA could be younger than previously thought. Similarly, Gelfo et al. (2009) regarded the Riochican as intermediate in age between that of the Itaboraian SALMA and the Paso del Sapo fauna. According to data herein utilized, we believe that the Itaboraian SALMA, and not the Riochican, represents the latest Paleocene-early Eocene span. In addition, taking into account the age suggested for Itaboraí, we concur with Gelfo et al. (2009) that the Riochican SALMA is intermediate in age between the Itaboraian and the Paso del Sapo associations; that is, early Eocene, probably spanning 51-50 My. As suggested by Marshall et al. (1997), the Riochican is very probably coeval to a sea-level highstand from the early Eocene and not from the latest Paleocene.

\section{PHYLOGENETIC ANALYSIS}

A phylogenetic analysis including late Cretaceous and Paleogene marsupials was performed using PAUP* $4.0 \mathrm{~b} 10$
(Swofford, 2003). Characters 1, 5, 8-10, 16, 18, 20, 25-26, 29, 34, $39,47-49,51-52,62,68-69$, and 72-73 were ordered. All characters were considered unweighted and the numbers on the nodes (Figure 5A) indicate the bootstrap support values (>50\% only). Details regarding the distribution of synapomorphies are given in the Phylogenetic Analysis section. Characters used in the phylogenetic analysis were taken from several studies, mainly from Reig et al. (1987), Cifelli (1993), Cifelli \& Johanson (1994), Johanson (1996), Oliveira (1998), and Goin et al. (1998a, 1999, 2006). Kokoppelia juddi, from late Cretaceous of North America is choice as the outgroup (Ciffeli, 1993; Ciffeli \& Muizon, 1997). The genus Alphadon, used in some papers as outgroup (e.g. Goin et al., 2009), was considered as a stem branch of all South American marsupials by Clemens $(1966,1979)$. However, "Alphadon" sensu Clemens (1966) is currently regarded as a polyphyletic taxon, including even didelphimorphian and polydolopimorphian forms according to Case et al. (2005).

\section{Taxon sample}

In order to establish the closer phylogenetic relationships of the taxa described herein, five well represented Metatheria genera of Tiupampa, Bolivia, were included in the analysis: Khasia, Pucadelphys, Tiulordia, Szalinia and Roberthoffstetteria. Eobrasilia and Riolestes were excluded from the analysis because its preservation prevents coding a great number of the characters. The two main lineages of Recent Didelphimorphia (Didelphidae and Caluromyidae) are represented by the generalized genera Philander and 

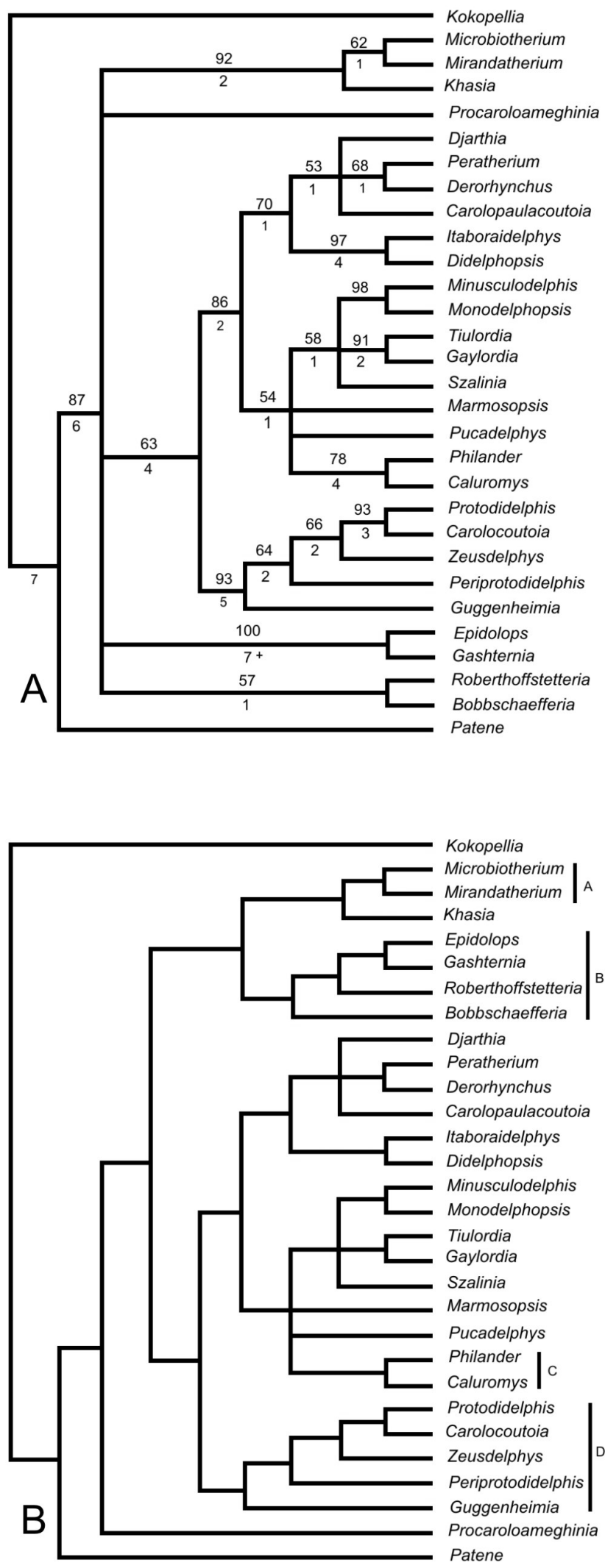

Figure 5. Cladograms of late Cretaceous and Paleogene metatherian relationships, including some Itaboraian bunodont taxa. $\mathbf{A}$, bootstrap analysis trees, with support values $>50 \%$ only; numbers below branches represent Bremer support values. B, most parsimonious cladogram from a heuristic search in PAUP with letters indicating the taxonomic nodes discussed in the text: A, Microbiotheriidae; $B$, Polydolopimorphia; C, Didelphidae; D, Protodidelphidae.
Caluromys. The Australian Djarthia and the European and North American genus Peratherium are included in the analysis. The status of some Itaboraian metatherians results from the taxonomy review of Oliveira (1998) on the basis of materials from MNRJ, MCT (DGM/DNPM) previously studied by Marshall (1987). The main conclusions include: (i) identification of upper molars for Derorhynchus (MNRJ 2506V) as well as new lower dentition as DGM 812-M (previously regarded as Monodelphopsis by Marshall, 1987) which the second lower incisor (i3) is staggered (Oliveira, 1998, see also Goin et al. 2009); (ii) identification of new upper molars of Gaylordia and Minusculodelphis (Oliveira \& Goin, 2006); (iii) exclusion of previously referred upper molars such as MNRJ 2506-V to Mirandatherium and DGM 803-M to Carolopaulacoutoia; (iv) Monodelphopsis hypodigm was reduced only to the type specimen and MNRJ 2340-V; and (v) new specimens and others previously referred to Monodelphopsis (DGM 649-M), Carolopaulacoutoia (DGM 920-M), Mirandatherium (DGM 922-M; DGM 1362-V) are identified as Peradectidae (Oliveira, 1998, Oliveira \& Goin, 2003). In this paper new taxonomical arrangement are reported for Bobbschaefferia, Gugenheimia, and Protodidelphis. The recognition of the upper dentition of Procaroloameghinia was made by Goin et al. (1998a) and Goin (2006).

\section{Metatheria classification}

We follow the suggestion of Sánchez-Villagra et al. (2007, see Apendix I) which the Marsupialia is restricted to crown marsupials. The cohort Ameridelphia is used with caution given the alternative proposals of Cifelli \& Johanson (1994), Oliveira \& Goin (2006) and Goin \& Candela (2004). Our concept of the taxon Didelphimorphia follows that of Horowitz et al. (2008, 2009).

$$
\begin{gathered}
\text { SYSTEMATIC PALEONTOLOGY } \\
\text { Class MAMMALIA Linnaeus, } 1758 \\
\text { Infraclass METATHERIA Huxley, } 1880 \\
\text { Cohort “AMERIDELPHIA" Szalay, } 1982 \\
\text { "AMERIDELPHIA" incertae sedis } \\
\text { Family PROTODIDELPHIDAE Marshall, } 1987
\end{gathered}
$$

Included genera. Carolocoutoia Goin, Oliveira \& Candela, 1998; Guggenheimia Paula Couto, 1952b; Protodidelphis Paula Couto, 1952b; Periprotodidelphis gen. nov., and Zeusdelphys Marshall, 1987.

\section{Genus Protodidelphis Paula Couto, 1952}

1952b Protodidelphis Paula Couto, p. 5. 1962 Protodidelphis Paula Couto, p. 141. 1970a Protodidelphis Paula Couto, p. 20. 1987 Robertbutleria Marshall, p. 122.

Type species. Protodidelphis vanzolinii Paula Couto, 1952. Included species. Protodidelphys vanzolinii and $P$. mastodontoides. 
Distribution. Itaboraí Basin, Rio de Janeiro, Brazil; Las Flores, Central Patagonia, Argentina; La Barda, Paso del Sapo and Laguna Fria localities, western Patagonia, Argentina; latest Paleocene-early Eocene (Itaboraian SALMA) to late early Eocene of South America.

Comments. Paula Couto (1952b, 1970) compared Protodidelphis vanzolinii with the living Didelphis marsupialis and with Tertiary genera of Argentina such as Paradidelphis and Cladodidelphis. Clemens (1966) listed some similarities between the late Cretaceous North American taxon Turgidodon rhaister and Protodidelphis. Paula Couto (1979) compared Protodidelphis with Glasbius from the late Cretaceous of North America. Crochet (1980) and Reig et al. (1987) also compared Protodidelphis and Glasbius, including both within the same subfamily, Glasbiinae. Marshall (1987) compared Protodidelphis with Bobbschaefferia, Guggenheimia, Reigia and Zeusdelphys, including all within Protodidelphinae, which he recognised as a subfamily of Didelphoidea. Marshall et al. (1990) included Protodidelphis, together with Bobbschaefferia, Guggenheimia, Procaroloameghinia, and "Robertbutleria", within Protodidelphidae, but placed this family in Polydolopimorphia. Finally, Goin et al. (1998a) described Carolocoutoia ferigoloi, from Itaboraí Basin, reuniting it with Protodidelphis, Guggenheimia, and "Robertbutleria" within Protodidelphidae, which was considered to be within "Didelphimorphia".

Protodidelphis vanzolinii Paula Couto, 1952 (Figures 6,7A-C, 8A; Table 1)

1952b Protodidelphis vanzolinii Paula Couto, p. 6, fig. 3. 1962 Protodidelphis vanzolinii Paula Couto, p. 141, fig. 2. 1970 Protodidelphis vanzolinii, Paula Couto, p. 20.

1987 Protodidelphis vanzolinii Marshall, p. 120, figs. 34-38.

Holotype. DGM 271-M, left rostral and palatal portion of the skull with roots of P1-2 and complete P3-M1 and M4, plus alveoli of $\mathrm{C} 1$ and M2-3.
Hypodigm. Holotype plus DGM 303-M, an incomplete right maxilla with complete M1-4; MNRJ 2897(a)-V, incomplete left m2; MNRJ 1427-V, right M4; DGM 319-M, left dentary with alveolus of i5, alveolus of $\mathrm{c} 1$, complete $\mathrm{p} 1$ and $\mathrm{p} 3$, roots of $\mathrm{p} 2$ and alveoli of m1-4; DGM 250-M, incomplete right dentary with $\mathrm{p} 3-\mathrm{m} 1, \mathrm{~m} 3$ and $\mathrm{m} 4$ (lacking their lingual sides), posterior portion of the alveolus of $\mathrm{c} 1$ and roots of $\mathrm{p} 1-2$ and $\mathrm{m} 2$; AMNH 49857 (ex DGM 320-M), almost complete right dentary with alveolus of c1, complete $\mathrm{p} 1-\mathrm{m} 1$, roots of $\mathrm{m} 2-3$, anterior roots and talonid of m4; MCN-PV 1805, incomplete left m1; AMNH 49803, (ex MNRJ 1370-V), right m2; MCN-PV 1818, almost complete right $\mathrm{m} 2$; MCT 2827-M, almost complete right $\mathrm{m} 2$; MCT 2828-M, almost complete right m2; MCN-PV 1821, almost complete left m4; MCN-PV 1821, complete left m4; MNRJ 2898-V, left m2? (see Paula Couto, 1970:20).

Locality and age. Itaboraí, Rio de Janeiro State, Brazil. Itaboraí Basin, latest Paleocene-early Eocene (Itaboraian SALMA).

Diagnosis. Differs from Protodidelphis mastodontoides in that the upper and lower molars are less bunoid, StB and StC are connected by a very sinuous, zigzag-like crest on M1-4; M3-M4 with much larger StA; preparacrista ending curved labially and connecting to StB; pre- and postprotoconal cingula absent; lower molars with the trigonid cusps higher than the talonid cusps; there is no wrinkled enamel within the talonid basin; m2-4 with the hypoconulid less robust and the entoconid closer to the metaconid.

Description. Premolars (DGM 271-M) increase markedly in size from P1 to P3; P1 is small and separated from P2 by a diastema; judging from the alveoli, P2 was slightly compressed labiolingually; P3 is larger than the P2; it is inflated, subovate in outline, and less robust than M1. M1 (DGM 303-M; Figure 6) is the smallest molar of the series, and shows low and somewhat inflated cusps; there is no ectoflexus; the stylar shelf is narrow to moderately reduced and has large $\mathrm{StB}$ and $\mathrm{StD}$; StB is slightly larger and connected to $\mathrm{StD}$ by a zigzag-like crest; StA is moderate in size, and is separated by a fissure from the StB; the metacone is clearly higher and more robust than the paracone; the centrocrista is low and V-shaped, but not labially invasive; the preparacrista

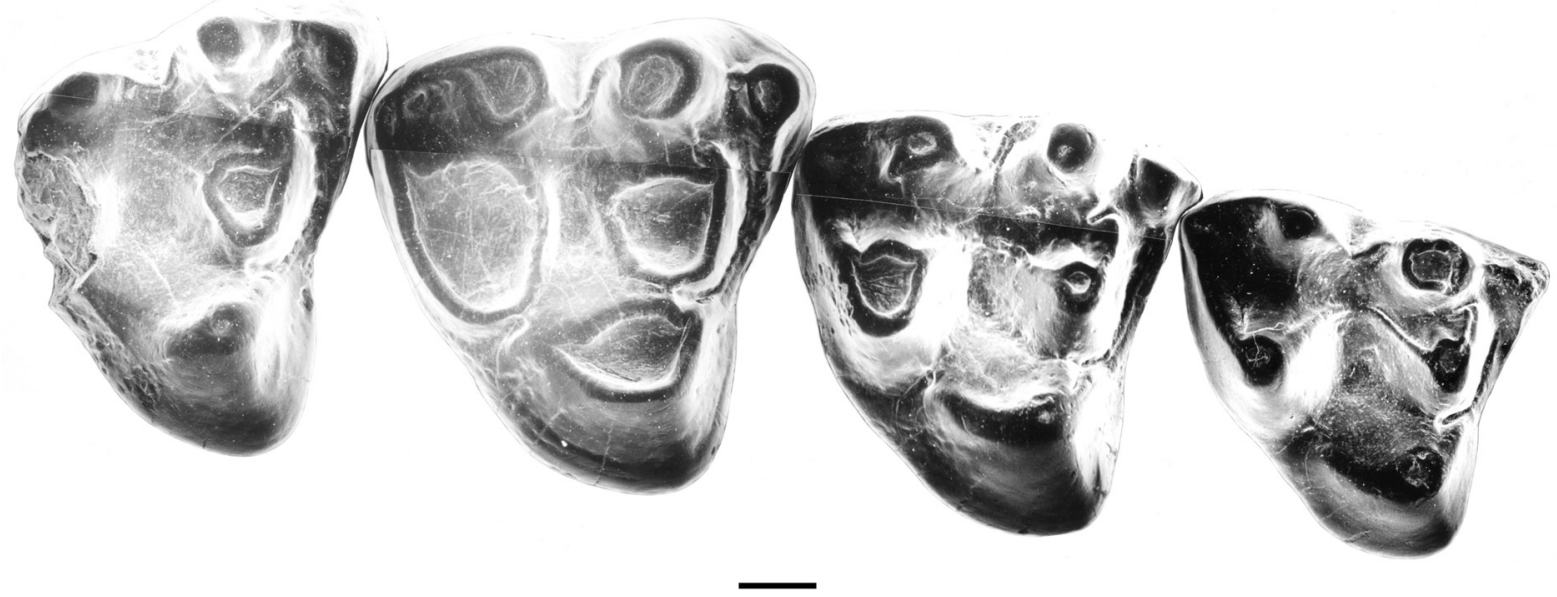

Figure 6. Upper teeth of Protodidelphis vanzolinii (DGM 303-M) in occlusal view. Scale bar $=1 \mathrm{~mm}$. 
is very short, ending curved labially and connecting the anterolingual face of $\mathrm{StB}$; the postmetacrista is only moderately developed; the metacone is anteriorly compressed; the protocone is not wide and is eccentric, so that it is nearly aligned to the StB in relation to the transversal dental axis; the anterolabial cingulum is narrow, but continuous with the preparacrista; there are no traces of paraand metaconule. M2 (DGM 303-M; Figure 6) differs from M1 by in its abruptly larger size, presence of a more sinuous zigzag-like crest between $\mathrm{StB}$ and $\mathrm{StD}$, and a more curved preparacrista. Specimen MNRJ 2897(a)-V differs from DGM 303-M in having the parastylar region slightly more developed. M3 (DGM 303-M; Figure 6) is much larger than M1 and M2; it differs from these teeth in having a less triangular outline, $\mathrm{StA}$ is larger and rounded, the ectoflexus is deeper and the parastylar region more salient labially. M4 (DGM 303-M; Figure 6; DGM 271-M) DGM 303-M lacks part of the posterolabial region. Its size is intermediate between that of M2 and M3; it differs from M1-3 in having the parastylar region more projected labially and the StD slightly less developed; the zigzag-like crest connects the StD in a more labial position; the metacone/paracone size relation shows some variability, with the paracone slightly more robust on the type specimen and in DGM 303-M, but equal in size to the metacone on MNRJ 1427-V.

Dentary and lower dentition. Morphological details of the lower molar sequence of this species are poorly known. Marshall (1987) referred two incomplete dentaries, of which the first (DGM 250-M) has only the $\mathrm{p} 3$ and $\mathrm{m} 1$ well preserved, with the m3-4 very incomplete; the second dentary (AMNH 49858) shows pm 2 and $\mathrm{pm} 3$ well preserved and $\mathrm{m} 1-2$ heavily worn. Thus, we regard the morphology of DGM 250-M as the most compatible in occlusion and complementary morphology with the upper dentition (see the explanation below). The dentary morphology is represented in the specimen DGM 319-M (Figure 8A); it is Didelphis-like, strongly convex above molars with the deeper point below $\mathrm{m} 4$.

Judging from its alveolus, the canine (DGM 250-M) was very large in relation to the premolars. Regarding the latter, p1 (DGM 250-M; 319-M) is small, two-rooted and with the alveoli aligned to the dental axis; $\mathrm{p} 1$ is separated from $\mathrm{p} 2$ by a diastema; $\mathrm{p} 2$ and $\mathrm{p} 3$ are two-rooted; $\mathrm{p} 3$ is most robust and more inflated than $\mathrm{p} 2$, being subequal in size to $\mathrm{m} 1 ; \mathrm{p} 2$ and $\mathrm{p} 3$ both have a short posterobasal heel. The trigonid of $\mathrm{m} 1$ (MCN-PV 1805; Figure 7A) is slightly narrower than the talonid; its cusps are poorly inflated; the paraconid is smaller than the metaconid and is placed slightly less lingually; the metaconid is placed slightly posteriorly to the protoconid in relation to the transversal dental axis; the talonid is welldeveloped, with the hypoconid very salient labially and subequal in height to the entoconid; the encotoconid is welldeveloped and conical, with its base occupying most of the lingual half of the talonid; the hypoconulid is small and placed close to the posterolabial face of the entoconid; on the distal edge of the talonid, a well developed wear facet is observed between the hypoconid and the hypoconulid; the cristid obliqua ends anteriorly very close to the posprotocristid notch; there are no traces of either a postentocristid or

Table 1. Measurements of upper and lower molars of Protodidelphis vanzolinii.

\begin{tabular}{|c|c|c|c|c|c|c|c|c|c|c|c|c|}
\hline Upper & L P2 & W P2 & L P3 & W P3 & L M1 & W M1 & L M2 & W M2 & L M3 & W M3 & L M4 & W M4 \\
\hline DGM 271-M & $\sim 3.8$ & - & 4.51 & 2.83 & 4.66 & 4.34 & - & - & - & - & 4.90 & 5.35 \\
\hline DGM 303-M & & & & & 4.97 & 5.41 & 5.63 & 5.61 & 5.62 & 5.84 & 4.91 & 5.58 \\
\hline MNRJ 1427-V & & & & & & & & & & & 5.15 & 5.16 \\
\hline MNRJ 2897(a)-V & & & & & & & 5.05 & 5.26 & & & & \\
\hline Lower & $\mathrm{Cp} 2$ & L p2 & $\mathrm{Cp} 3$ & L p3 & $\mathrm{C} \mathrm{m} 1$ & $\mathrm{~L} \mathrm{~m} 1$ & $\mathrm{C} \mathrm{m} 2$ & L m2 & $\mathrm{C}$ m3 & $\mathrm{L} \mathrm{m} 3$ & $\mathrm{C} \mathrm{m} 4$ & $\mathrm{~L} \mathrm{~m} 4$ \\
\hline AMNH 49803 & & & & & & & 5.10 & 3.29 & & & & \\
\hline AMNH $49857 *$ & 3.5 & 2.0 & - & - & 4.8 & 3.0 & - & - & - & - & - & 3.5 \\
\hline DGM 250-M & & & 4.45 & 2.79 & 4.64 & 2.92 & - & - & 5.50 & 3.67 & 5.53 & - \\
\hline DGM 319-M & - & - & 4.2 & 2.6 & - & - & - & - & - & - & - & - \\
\hline MCN-PV 1805 & & & & & 4.33 & 2.90 & & & & & & \\
\hline MCN-PV 1818 & & & & & & & 4.88 & 3.45 & & & & \\
\hline MCN-PV 1821 & & & & & & & & & & & 5.11 & 3.05 \\
\hline МСТ 2827-M & & & & & & & 5.2 & 3.4 & & & & \\
\hline MCT 2828-M & & & & & & & 5.0 & 3.2 & & & & \\
\hline MNRJ 2898-V & & & & & & & & & 4.6 & 3.4 & & \\
\hline
\end{tabular}

$* \mathrm{Cp} 1=2.1 ; \mathrm{L} \mathrm{p} 1=1.3$ 
postcingulid. In comparison with the m1 of DGM 250-M, referred to Protodidelphis vanzolinii, this tooth differs only in having the hypoconulid slightly more developed. The $\mathrm{m} 2$ (MCT 2827-M; Figure 7C) occludes well with the M2 of DGM 303-M; the trigonid cuspids are slightly higher than those of the talonid; the paraconid shows a small accessory cuspule on its lingual side; it differs from the $\mathrm{m} 1$ in being larger, the paraconid is less developed, and the entoconid is slightly less developed; the anterior cingulid is narrow and weakly extended labially. MCT 2828-M is nearly identical to MCT 2827-M. AMNH 49803 is very similar to the other m2's. MCNPV 1818 (Figure 7B) differs from MCT 2827-M only in having stronger cuspids; this tooth shows two fractured roots, which are subrectangular in outline. The m4 (MCN-PV 1821) differs from the m1-3 in its slightly smaller size, the trigonid and talonid are subequal, the paraconid is placed less lingually than the metaconid and is slightly less compressed anteroposteriorly, the hypoconid is labially compressed and the hypoconulid is posteriorly more salient. A small portion of the mesial root of $\mathrm{m} 4$ is preserved; it is subcircular in outline and has a greater diameter than the distal root, which is also subcircular, and relatively short and slender.

As shown above, the discovery of several isolated molars of this species shed new data on their dental morphology. Protodidelphis vanzolinii was a species with bunodont teeth
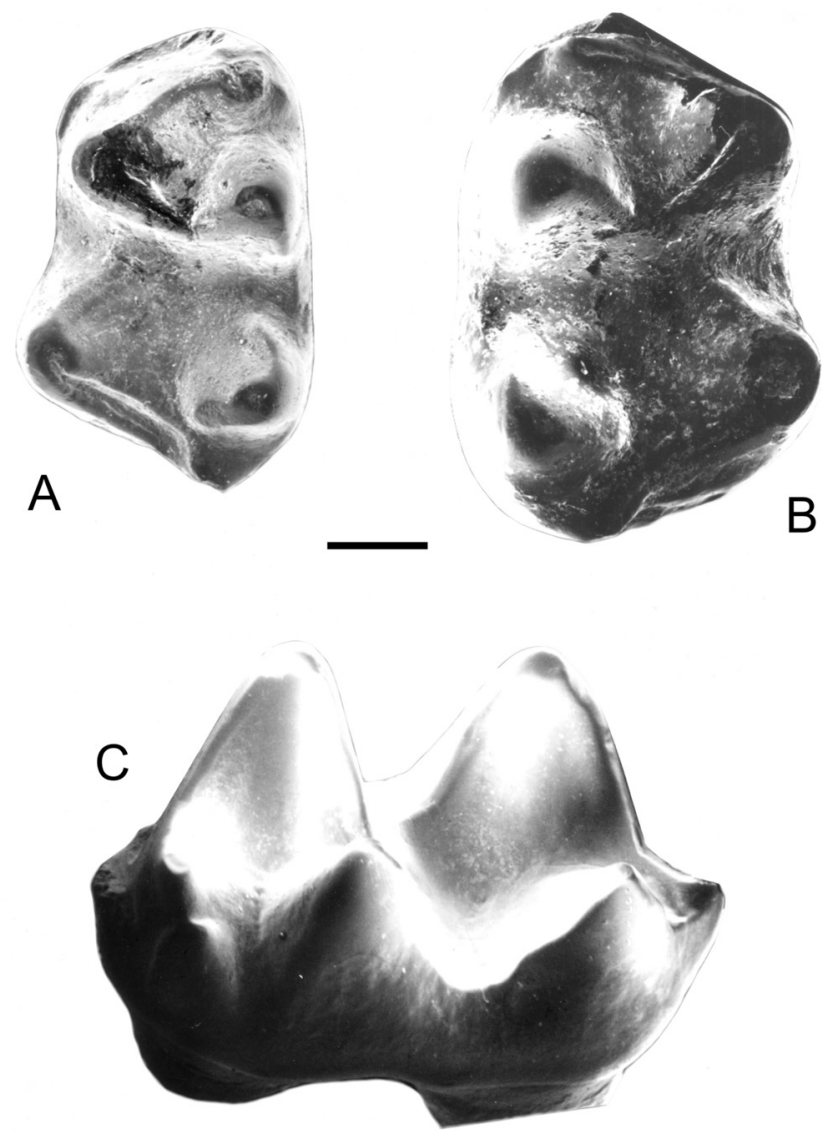

Figure 7. Lower teeth of Protodidelphis vanzolinii. A, MCN-PV 1805, m1 in occlusal view; B, MCN-PV 1818, m2 in occlusal view; C, MCT 2827-M, m2 in lingual view. Scale bar = $1 \mathrm{~mm}$. and moderately low cusps, probably related to omnivory (Paula Couto, 1970), which is also suggested by the presence of moderately developed shearing crests.

Protodidelphis mastodontoides (Marshall, 1987) (Figures 9A-E; Table 2)

1987 Robertbutleria mastodontoidea Marshall, p. 123, fig. 39.

Holotype. DGM 896-M, a complete left M1.

Hypodigm. The holotype and MCT 2769-M (ex DGM 896bM), a complete left M2; MCN-PV 1799, a complete left dP3; MCN-PV 1806, a complete left M3; MNRJ 2897(b)-V, a nearly complete right M2; MNRJ 2897(c)-V, an incomplete right M2; MNRJ 2897(d)-V, an incomplete left M3; AMNH 49858, an incomplete left dentary with p2-m2; MCT 2817-M, a nearly complete left m2; MCT 2818-M, a nearly complete left m2; MCT 2819-M, an incomplete left m2; MNRJ 1371-V, a complete left m1; MCN-PV 1819, a nearly complete left m3; MCN-PV 1816, a nearly complete left m3; MCN-PV 1817, an incomplete left m3; MCN-PV 1820, a complete left m4.

Locality and age. Itaboraí, Rio de Janeiro State, Brazil. Itaboraí Basin, latest Paleocene-early Eocene (Itaboraian SALMA).

Diagnosis. Differs from Protodidelphis vanzolinii in having the upper and lower molars with more inflated cusps, StB and $\mathrm{StD}$ are connected by a less sinuous zigzag-like crest, the pre- and postprotoconal cingula are present, StA is smaller (at least on M3), M1 and M2 with vestigial metaconule; p3 is more inflated; the lower molars have wrinkled enamel within the talonid basin; the labial cingulid on $\mathrm{m} 1$ is narrow but is not short; finally, the entoconid is more widely separated from the metaconid.

Description. The dP3 (MCN-PV 1799; Figure 9A) lacks any traces of an ectoflexus; the paracone is fused to the StB; the preparacrista ends labially without connecting to a stylar cusp; the protocone is placed well anteriorly; the tooth has pre- and postprotoconal cingula; at the apex of the centrocrista, a well marked labiolingual wear facet is present, which ends close to the anterior face of the StD.

The M1 (DGM 896-M; Figures 9B-C) is approximately equal in all its dimensions, showing a less triangular outline than the homologous tooth of $P$. vanzolinii; the cusps are low and inflated; the stylar shelf is moderately reduced and the trigon and stylar cusps are equal in height; on the lingual face of the trigon, the enamel is wrinkled, as well as on the labial face of the stylar shelf; the ectoflexus is poorly marked; the labial cingulum is narrow StA is small, and is placed well below the level of the remaining stylar cusps; $\mathrm{StB}$ is the most robust stylar cusp, and is slightly higher than $\mathrm{StD}$; there are no traces of $\mathrm{StC}$ or StE; StD is slightly compressed labiolingually; the zigzag-like crest linking StB and StD is only slightly sinuous. A labial cingulum is present, as well as pre- and postprotoconal cingula. Two poorly marked crests originate from StD: the first one is straight and connects to $\mathrm{StB}$; the second crest is longer and connects to the posterolabial corner of the tooth. The preparacrista is short and poorly marked; the metacone is higher and more robust 
than the paracone; the centrocrista is low and V-shaped; the protocone is eccentric; there are no traces of para- and metaconule, but a very small vertical crest on the posterolingual face of the protocone might constitute a vestigial metaconule; only the lingual and the posteriolabial roots of the tooth are preserved, with both similar in size and subcircular in outline. M2 [MCT 2769-M (ex DGM 896-M(b)] differs from M1 in its larger size; pre- and postprotoconal cingula not connected to each other; $\mathrm{StB}$ and $\mathrm{StD}$ are connected by a zigzag-like crest; finally, there is a vestigial metaconule. Specimen MNRJ 2897(b)-V differs from MCT 2769-M only in its slightly larger size. Specimen MNRJ 2897 (c)-V is the largest molar (Table 2). This tooth exhibits the characteristic zigzag-like crest between StB and StD. M3 (MCN-PV 1806) differs from M2 in being of larger size; the preprotocrista and the postmetacrista are of equal length, and the pre- and postprotoconal cingula are less developed than in $\mathrm{M} 2$.

Lower teeth. AMNH 48858 is interpreted as pertaining to P. mastodontoides. The most notable difference is in $\mathrm{p} 3$, which is clearly more inflated than the same tooth of DGM 250-M, which has been referred to Protodidelphis vanzolinii. The first and the second lower molars are transversely more developed than those of $P$. vanzolinii, with the entoconid lingually more salient and with the hypoconulid more displaced posteriorly. The other distinct character of this tooth is the wide distance between the distal side of the metaconid and the entoconid. m1 (MNRJ 1371-V) and m2 (MCT 2818-M; Figures 9D-E). $\mathrm{m} 2$ differs from $\mathrm{m} 1$ because of its slightly larger size, the paraconid is more lingually placed and more compressed anteroposteriorly, and the postcingulid is better developed. In both teeth the enamel is wrinkled within the talonid basin; the cuspids are inflated and there is little difference in height between the trigonid and the talonid; the anterior cingulid is well developed and extends to the anterolabial corner of tooth; the paraconid and the metaconid are robust and very close to each other, with the metaconid more robust and conical than the paraconid; the entoconid has the characteristic conical aspect of protodidelphids, and is well separated from the posterior wall of the trigonid; the hypoconulid is robust and is placed lingually, still nearly terminal and twinned with the entoconid. The trigonid of $\mathrm{m} 3$ (MCN-PV 1816) is anteroposteriorly compressed and is transversely equal in width to the talonid; the pre- and postprotocristid are similar in length; the anterior cingulid is narrow, well extended labially and reatively continuous with the labial cingulid; the talonid has a wide basin and, as in the remaining teeth, the enamel is wrinkled within the basin; the entoconid is well developed, conical, and well separated from the metaconid; the cristid obliqua ends anteriorly well labially to the postprotocristid notch; the entoconid is conical and extended lingually, occupying most of the lingual edge of the talonid; the anterocingulid is short and extends only weakly labially. The $\mathrm{m} 4$ (MCN-PV 1820) differs from m1-3 in having the labial cingulum less developed; the talonid is slightly

Table 2. Measurements of upper and lower molars of Protodidelphis mastodontoides.

\begin{tabular}{|c|c|c|c|c|c|c|c|c|c|c|c|c|}
\hline Upper & LP2 & W P2 & LDP3 & W DP3 & L M1 & W M1 & L M2 & W M2 & L M3 & W M3 & L M4 & W M4 \\
\hline DGM 896-M & & & & & 4.48 & 4.63 & & & & & & \\
\hline MCT 2769-M & & & & & & & $\sim 5.0$ & 5.21 & & & & \\
\hline MCN-PV 1799 & & & 3.93 & 3.58 & & & & & & & & \\
\hline MCN-PV 1806 & & & & & & & 5.50 & 5.88 & & & & \\
\hline MNRJ 2897(b)-V & & & & & & & 5.31 & 5.29 & & & & \\
\hline MNRJ 2897(c)-V & & & & & & & & & 5.78 & 6.06 & & \\
\hline Lower & $\begin{array}{l}\mathrm{L} \\
\mathrm{p} 2\end{array}$ & W p2 & $\begin{array}{l}\text { L } \\
\text { p3 }\end{array}$ & W p3 & $\mathrm{L}$ m1 & W ml & $\mathrm{L}$ m2 & $\mathrm{W} \mathrm{m} 2$ & $\mathrm{~L}$ m3 & W m3 & $\mathrm{Lm} 4$ & $\mathrm{~W}$ m4 \\
\hline AMNH 49858 & 3.65 & 2.37 & 4.84 & 2.98 & 5.25 & 3.34 & 5.81 & 4.01 & & & & \\
\hline MCN-PV 1816 & & & & & & & & & 6.03 & 3.63 & & \\
\hline MCN-PV 1817 & & & & & & & & & 5.81 & 3.82 & & \\
\hline MCN-PV 1819 & & & & & & & & & 6.19 & 4.18 & & \\
\hline MCN-PV 1820 & & & & & & & & & & & 5.71 & 3.51 \\
\hline MCT 2817-M & & & & & & & 5.6 & 3.6 & & & & \\
\hline MCT 2818-M & & & & & & & 5.5 & 3.8 & & & & \\
\hline MCT 2819-M & & & & & & & 5.4 & 3.7 & & & & \\
\hline MNRJ 1371-V & & & & & 4.97 & 3.16 & & & & & & \\
\hline
\end{tabular}


more compressed labiolingually than the trigonid; the hypoconid and the entoconid are slightly less developed; the hypoconulid is placed almost centrally on the distal edge of the talonid; the postcingulid is very poor developed; only the most proximal portion of the two roots are preserved, with the anterior root wider and subrectangular in outline; its distal face has a small concavity; the posterior root is slender and has a subtriangular outline.

Comments. In the original description of Robertbutleria, Marshall (1987) made brief comparisons with Protodidelphis in the diagnosis and only with Glasbius (from the Late Cretaceous of North America) in the discussion. In this same paper he suggested a close relationship between "Robertbutleria" and Protodidelphis, including them within the family Caroloameghiniidae, but in distinct subfamilies. As previously suggested by Oliveira (1998) and later by Oliveira \& Goin (1999), "Robertbutleria" is regarded as junior synonym of Protodidelphis based on the following aspects: (i) the genus is not closely related to Caroloameghiniinae/ Caroloameghiniidae (see phylogenetic analysis, and also Goin, 2006; Goin \& Candela, 1996; Goin et al., 1998a); (ii) in the description of "R. mastodontoides", Marshall (1987) did not report two important derived characters present on the holotype of Protodidelphis vanzolinii and in " $R$." mastodontoides: the great size diference between M1-2 and the presence of a zigzag-like crest connecting StB and StD; (iii) during this study, the MCN-PV 1806, consisting of an M3 of " $R$." mastodontoides was identified, which was previously described by Goin et al. (1998a), that corroborates the close relationship between "Robertbutleria" and Protodidelphis. Both show a rapid increase in size from M1 to M3. In short, we interpret that the characters that distinguish "Robertbutleria" and Protodidelphis are of a specific, not generic nature. The specific name is modified to mastodontoides, instead of mastodontoidea, because the first is the correct epithet of the male gender Protodidelphis.

Protodidelphis mastodontoides is morphologically similar to Protodidelphis vanzolinii. Marshall (1987) proposed "Robertbutleria" on the basis of DGM 896-M (holotype), interpreted as an M1, and MCT 2769-M (ex DGM 896b-M), interpreted as an M2. As discussed above, one of the distinctive features that separate Protodidelphis from other "opossum-like" metatherians is the abrupt increase in size from M1/m1 to M3/m3 (Goin et al., 1998a). Specimen MCNPV 1806, identified by us as a M3 of $P$. mastodontoides, deserves comment: it is clearly larger than the other two upper molars of P. mastodontoides (see Marshall, 1987), and illustrate the rapid size increase from $\mathrm{M} / \mathrm{m} 1$ to $\mathrm{M} / \mathrm{m} 3$ that is a diagnostic character also recorded in Protodidelphis vanzolinii. Besides the larger size relative to M2, other differences between specimen MCN-PV 1806 and the other molars of the DGM collection can be interpreted as related to this abrupt size increase. This is illustrated in DGM 896a-M (M1), where the preprotoconal cingulum is continuous posteriorly with the postprotoconal cingulum; in DGM 896b-M (M2) the preand post-protoconal cingula are not connected to each other, being interrupted on the lingual face of the protocone. Finally, in the specimen MCN-PV 1806 (M3), both cingula are shorter and more clearly separated from each other. The postmetacrista of this last specimen also has the same length proportion in relation that of the M3 of Protodidelphis vanzolinii.

The size difference between the two species is illustrated in the length versus width relation of $\mathrm{m} 2$ (Figure 10). Regarding the dental morphology, one of the most notable differences is the more bunodont condition of $P$. mastodontoides, which has more inflated cusps. This condition is well illustrated in the lower molars here referred to $P$. mastodontoides, which have a lesser height difference between the trigonid and the talonid, and the cusps are clearly more inflated at their bases. Furthermore, the labial cingulum, present on the upper molars, is also present on the lower molars. Another important aspect is related to the protocone morphology, which in $P$. mastodontoides is much wider and less acute than in $P$. vanzolinii. The lower molars show the entoconid less conical and more worn than those of $P$. vanzolinii. These features agree well with the wider protocone of the upper molars.

\section{Genus Guggenheimia Paula Couto, 1952}

1952b Guggenheimia Paula Couto, p. 11.

1952b Schaefferia Paula Couto, p. 12 (partim).

1962 Guggenheimia Paula Couto, p. 148.

1987 Guggenheimia Marshall, p. 107.

Type species. Guggenheimia brasiliensis Paula Couto, 1952 Included species. Guggenheimia brasiliensis, and G. crocheti sp. nov.

Distribution. Itaboraí Basin, Rio de Janeiro, Brazil; Las Flores, central Patagonia, Argentina; Latest Paleocene-early Eocene (Itaboraian SALMA), South America.

Comments. In previous reviews of the "opossum-like" marsupials from Itaboraí (Paula Couto 1962, 1970; Marshall, 1987), the hypodigm of the genus Guggenheimia remained unaltered. Oliveira (1998) regarded only the type specimen (DGM 297-M) as belonging to this species. As seen in the synonym list of this genus, part of the hypodigm of Bobbschaefferia fluminensis (vide below) contain specimens herein assigned to the Guggenheimia.

\section{Guggenheimia crocheti sp. nov. (Figures 8B-E,11; Table 3)}

Holotype. DGM 314-M, an incomplete left dentary with m2-4 and alveoli of $\mathrm{i} 1-\mathrm{m} 1$.

Hypodigm. The holotype and DGM 315-M, an incomplete left dentary with $\mathrm{m} 3$, alveolus of $\mathrm{c} 1$, alveoli of $\mathrm{m} 2$ and anterior alveolus of m4; MNRJ 2899(a)-V, an isolated right m3; MCT 2783-M, an isolated left m3; MCT 2782-M, an isolated left M1.

Etymology. crocheti, honouring Jean-Yves Crochet, mammalian paleontologist of the Institut des Sciences de l'Évolution, Université Montpellier, France, in recognition of 


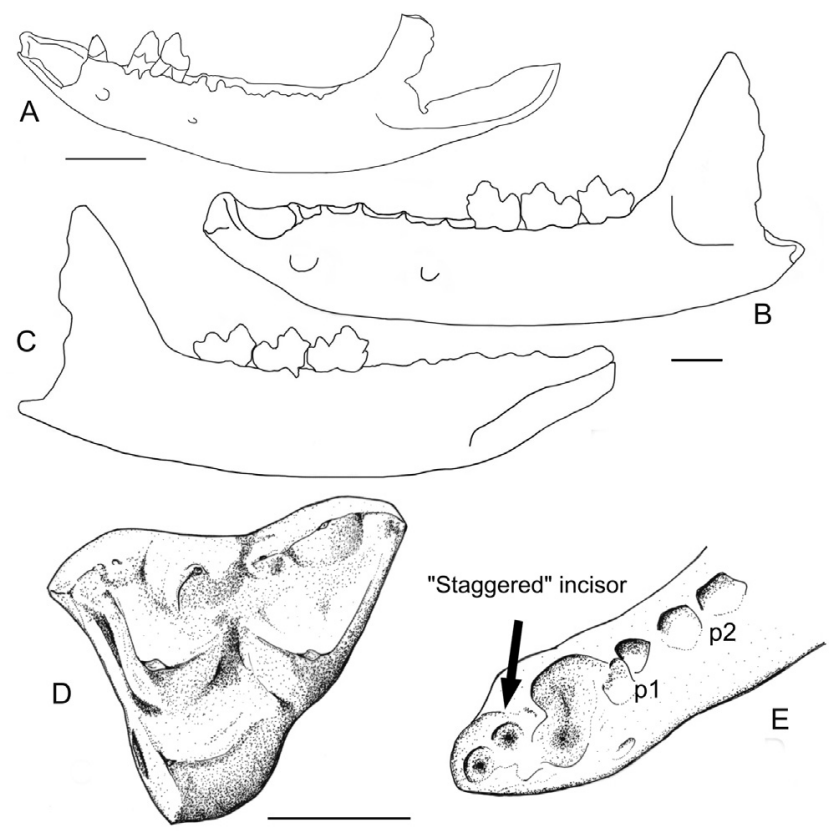

Figure 8. A, Left dentary of Protodidelphis vanzolinii (DGM 319-M) in lateral view; B, left dentary of Guggenheimia crocheti sp. nov. (DGM-314-M) in lateral view; C, left dentary of Guggenheimia crocheti sp. nov. (DGM-314-M) in lingual view; D, M1 of Guggenheimia crocheti sp. nov. (MCT 2782-M) in occlusal view; $\mathbf{E}$, Detail of incisor and canine alveoli of Guggenheimia crocheti sp. nov. (DGM-314-M). Scale bars: $\mathrm{A}=10 \mathrm{~mm} ; \mathrm{B}-\mathrm{C}=3 \mathrm{~mm} ; \mathrm{D}-\mathrm{E}=1 \mathrm{~mm}$. his very important studies on European and South American extinct metatherians.

Horizon and locality. Itaboraí Basin, Rio de Janeiro, Brazil (Figure1); latest Paleocene-early Eocene (Itaboraian SALMA). Diagnosis. Differs from Guggenheimia brasiliensis in its greater size, the anteriorly much longer and more robust dentary, paracononid more robust and more anterolabially positioned in m2-4, more inflated cusps, and p1 less obliquely placed relative to the dental axis.

Description. Compared to other "opossum-like" metatherians, the dentary is peculiar in the almost straight ventral edge and in the less vertical orientation of the symphysis, which is salient (in labial view) in its distal portion (Figures 8B-C). In Marmosopsis, Pucadelphys, and Recent didelphids the ventral border is convex and gently continuous with the symphysis (see Paula Couto, 1970: fig. 4; Muizon, 1991: fig. 5f).The dentary is anteriorly longer in comparison with the type species, being stronger and moderately tall; the symphy sis extends posteriorly to a point below the p 2 and is abruptly slender anteriorly; two mental foramina are present, with the anterior placed below the canine and p1, and the posterior below the anterior edge of $\mathrm{m} 1$. The incisor alveoli (DGM 314M; Figure 8E) show the most dorsal alveolus (i3) "staggered" (i.e. dorsally placed to the adjacent alveoli); the alveolus of $i 2$ is equivalent in size to that of $i 3$. The alveolus of the canine (Figure 8E) is relatively short anteroposteriorly. The first premolar (DGM 314-M) is not separated by a diastema from the canine and set oblique to dentary axis. The alveoli of p2
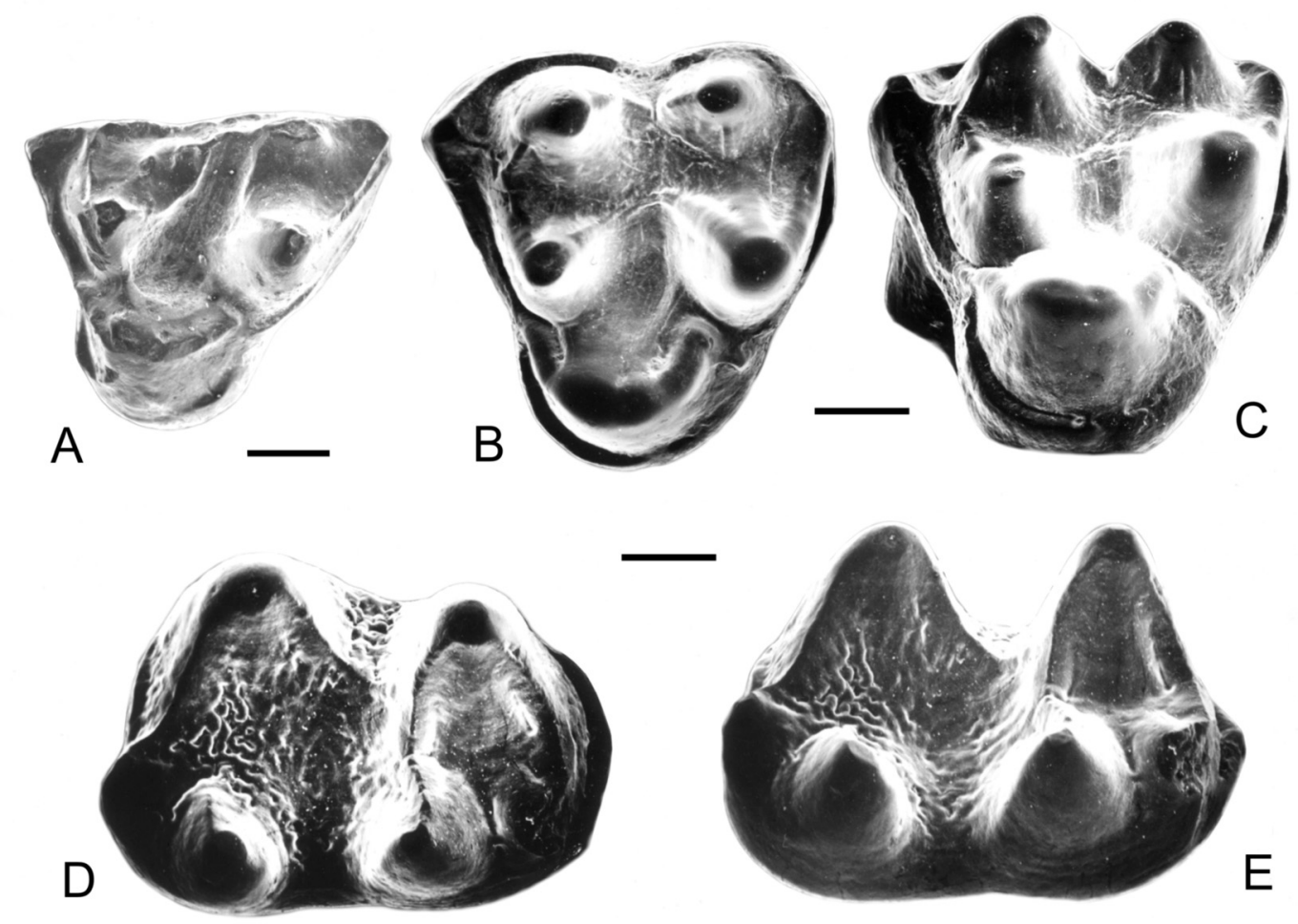

Figure 9. Upper and lower teeth of Protodidelphis mastodontoides. A, MCN-PV 1799, dP3 in occlusal view; B, DGM 896-M (holotype) in occlusal view; C, DGM 896-M in lingual-occlusal view; D, MCT 2818-M, m2 in occlusal view; E, MCT 2818-M, m2 in lingual-occlusal view. Scale bars $=1 \mathrm{~mm}$. 
Table 3. Measurements $(\mathrm{mm})$ of upper and lower molars of Gugenheimia.

\begin{tabular}{|c|c|c|c|c|c|c|c|c|c|c|c|c|c|c|c|c|}
\hline $\begin{array}{l}\text { Upper and } \\
\text { lower molars }\end{array}$ & LM2 & WM2 & Lp1 & Wp1 & $\mathrm{Lp} 2$ & W p2 & L p3 & W p3 & $\mathrm{Lml}$ & Wm1 & $\mathrm{Lm} 2$ & $\mathrm{Wm} 2$ & Lm3 & $\mathrm{Wm} 3$ & $\mathrm{Lm} 4$ & Wm4 \\
\hline MCT 2782-M & 3.20 & 2.90 & & & & & & & & & & & & & & \\
\hline DGM 297-M & & & 1.28 & 0.75 & 2.03 & 1.17 & 2.07 & 1.39 & 2.58 & 1.92 & 2.68 & 2.06 & 2.86 & 2.04 & 2.79 & 1.82 \\
\hline DGM 314-M & & & & & & & & & & & 3.04 & 1.98 & 3.17 & 2.02 & 3.15 & 1.62 \\
\hline МСТ 2783-M & & & & & & & & & & & & & 3.20 & 2.00 & & \\
\hline MNRJ 2899-V & & & & & & & & & & & & & 3.16 & 1.77 & & \\
\hline
\end{tabular}

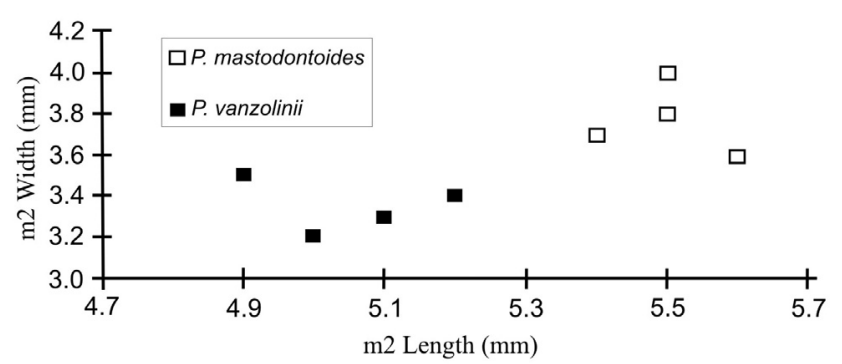

Figure 10. Length versus width scatter diagram of $\mathrm{m} 2$ of Protodidelphis vanzolinii and $P$. mastodontoides.

are placed aligned to the dental axis and are separated from the alveoli of $\mathrm{p} 1$ by a small diastema; the alveoli of $\mathrm{p} 2$ are approximately similar in size to that of $\mathrm{p} 3$.

Judging from its alveoli, the m1 (DGM 314-M) was slightly smaller than the $\mathrm{m} 2$. The $\mathrm{m} 2$ has the trigonid ligually open and transversely less developed than the talonid (Figure 11). The paraconid is moderate in size and is lingually aligned with the metaconid; the metaconid is located posterior to the protoconid; the preprotocristid is rounded; the postprotocristid is poorly developed; the anterior cingulid is anteriorly projected and shows an less inclined trajectory; the hypoconid is approximately comparable in height to the entoconid; the entoconid is conical, spire-like, occuping almost the ligual half of the talonid; there are no traces of preentocristid; the prehypocristid and the posthypocristid, which composes the cristid obliqua, are symmetrical; the cristid obliqua ends anteriorly just labial to the postprotocristid notch; the hypoconulid is moderate in size, it is dorsally compressed and is located at the corner of the talonid; the posthypocristid is more oblique than transversal to the dental axis; there is no vestige of a postcingulid. The m3 (DGM 314-M; Figure 11) differs from the $\mathrm{m} 2$ in having a less developed anterior cingulid and by the slightly more labially placed cristid obliqua relative to the postprotocristid notch. MCT 2783-M differs from the DGM 314-M in being slightly larger, by the metaconid somewhat inclined posteriorly and by the presence of a minute preentocristid, placed between the entoconid and the paraconid. In MNRJ 2899(a)-V the cristid obliqua ends anteriorly closer to the postprotocristid notch; the talonid is slightly narrower to the trigonid, and the hypoconulid is slightly less developed than in $\mathrm{m} 2$. The $\mathrm{m} 4$ (DGM 314-M; Figure 11) shows a similar morphology to that of $\mathrm{m} 2-3$, except for its smaller size, the talonid proportionally narrower and the entoconid less developed and more posteriorly placed in relation to the posterior wall of the trigonid.

MCT 2782-M (Figure 8D) is the only known upper molar. The tooth is anteroposteriorly large, with relatively low cusps and sharp crests; the stylar shelf is moderately developed; $\mathrm{StB}$ and StD are robust and very close to each other; StA and $\mathrm{B}$ are connected by a vestigial crest; StB is the most robust stylar cusp, showing a conical base and occupying a slightly more lingual position in relation to the remaining stylar cusps; $\mathrm{StC}$ is minute and connected to $\mathrm{StD}$ by a very low crest; $\mathrm{StD}$ is slightly lower than StB and is labiolingually compressed; the ectoflexus is well developed, with its deepest inflexion placed between $\mathrm{StB}$ and $\mathrm{StD}$; the preparacrista is relatively well developed and connects to StA; the postmetacrista is much longer than the preparacrista; the paracone is comparable in height to $\mathrm{StB}$; the metacone is the highest cusp, but it is comparable in robustness to the paracone; the premetacrista and the postparacrista are poorly developed so that these cristae do not connect to each other; the anterolabial cingulum is narrow, but continuous with the preprotocrista; the protocone is small and very eccentric; on its anterior face there is a short and narrow preprotoconal cingulum; there are no traces of a paraconule or metaconule. Only the lingual root is preserved, which is well developed, conical, and equivalent in diameter to the remaining roots.

Comments. Specimens DGM 314-M, DGM 315-M, and MNRJ 2899(a)-V were previously referred to Bobbschaefferia fluminensis (Paula Couto 1952a, 1962, 1970; Marshall, 1987). In relation to the specimen DGM 314-M, it is interesting that Crochet (1980) suggested that this material was incorrectly referred as the paratype of Bobbschaefferia fluminensis (Paula Couto, 1952a, 1962). This suggestion was followed by Goin et al. (1998a), who demonstrated that DGM 314-M belongs to Guggenheimia. Interestingly, G. crocheti sp. nov. is also identified for the Itaboraian locality of Las Flores, Central Patagonia, Argentina (Oliveira, 1998). Although similar in general characters to the specimens reported for Las Flores, the specimens of $G$. crocheti $\mathrm{sp}$. nov. from the Itaboraí locality are distinct in some characters. The specimen MNRJ 2891-V, identified as an $\mathrm{m} 1$, is comparable in size and morphology with MLP 90-II-5-56 from Las Flores, which differs from the 


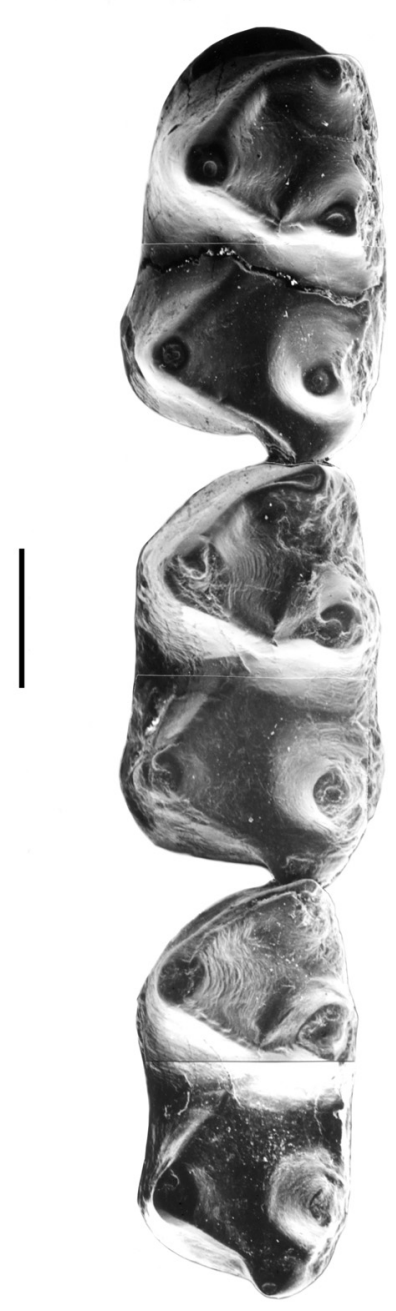

Figure 11. Guggenheimia crocheti sp. nov. (DGM-314-M, holotype), $\mathrm{m} 2-4$ in occlusal view. Scale bar $=1 \mathrm{~mm}$.

Itaboraí species by the more robust entoconid, presence of a vestigial metaconule and slightly larger size. The lower molars from Las Flores are also slightly larger than specimen DGM 314-M, but not so in relation to specimen MCT 2782-M, the size of which is comparable to that of the Las Flores specimens.

\section{Genus Carolocoutoia Goin, Oliveira \& Candela, 1998}

1998 Carolocoutoia Goin, Oliveira \& Candela, p. 147.

Type species. Carolocoutoia Goin, Oliveira \& Candela, 1998. Distribution. Itaboraí Basin, Rio de Janeiro, Brazil; latest Paleocene-early Eocene (Itaboraian SALMA).

Carolocoutoia ferigoloi Goin, Oliveira \& Candela, 1998 (Figure 12)

1998 Carolocoutoia Goin, Oliveira \& Candela, p. 148, fig. 1a.

Holotype and only known specimen. MCN-PV 1802, isolated upper left molar (M3?).

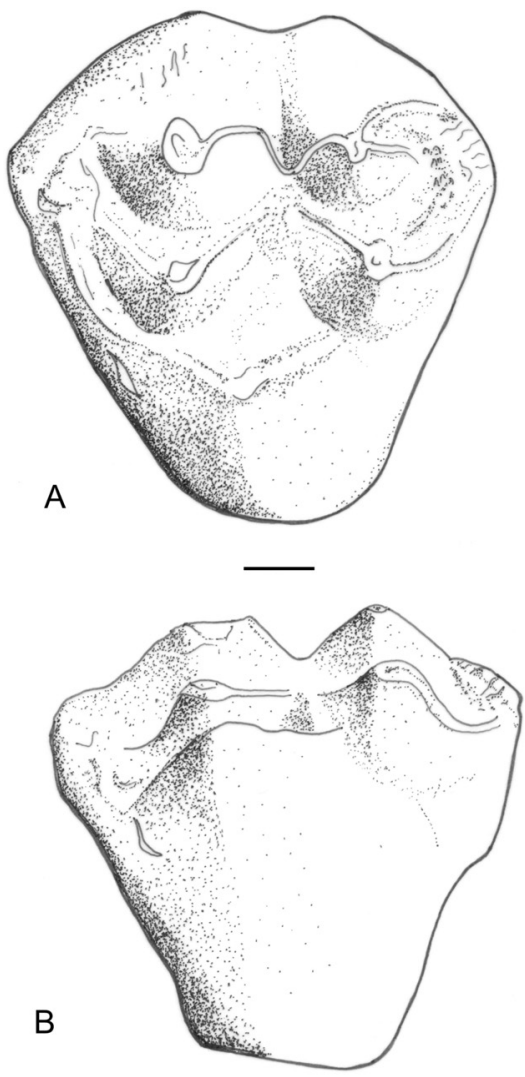

Figure 12. Carolocoutoia ferigoloi (MCN-PV 1802, holotype), upper left molar (M3?). A, occlusal view; $\mathbf{B}$, lingual view. Scale bar $=1 \mathrm{~mm}$.

Horizon and locality. Itaboraí Basin, Rio de Janeiro, Brazil (Figure1); latest Paleocene-early Eocene (Itaboraian SALMA). Revised diagnosis. Differs from other protodidelphids in having much more inflated cusps, very low crown, rounded crests without cutting edges, larger anterior cingulum, and wrinkled enamel on the labial face and at the anterolabial and posterolabial corners of the tooth.

Comments. In comparison with other protodidelphids, Carolocoutoia ferigoloi is most closely related to Protodidelphis based on the presence of a zigzag-like crest linking StB and StD (22.1). Goin et al. (1998a) observed that when compared with MCN-PV 1806 of P. mastodontoides, the type of $C$. ferigoloi appears to represent a more derived form. In both species the metastylar corner of M3 is wrinkled, and a short crista can be observed on the posterior slope of $\mathrm{StD}$, that extends from the base of this cusp (although this crista is better developed in P. mastodontoides). In addition, Carolocoutoia is larger, and has more inflated cusps and shorter cristae.

Carolocoutoia ferigoloi is one of the largest fossil or living "opossum-like" metatherians. Goin et al. (1998a) suggested for this species an extreme adaptation to a frugivorous diet because of the very low crown, reduced cristae, and inflated cusps. However, an omnivorous component to its diet cannot be rejected, given the bunodonty/omnivory relation observed in living Didelphis species. 


\section{Periprotodidelphis gen. nov.}

Etymology. From Greek peri: around, close to Protodidelphis, the type genus of the family Protodidelphidae.

Type species. Periprotodidelphis bergqvistae, sp. nov.

Distribution. Latest Paleocene-early Eocene (Itaboraian SALMA).

Diagnosis. As for the type and only known species.

\section{Periprotodidelphis bergqvistae sp. nov.} (Figure 13)

\section{Holotype. DGM 806-M, a complete left M?3.}

Hypodygm. The holotype only.

Etymology. In honour to Lilian Paglarelli Bergqvist, vertebrate paleontologist of the Universidade Federal do Rio de Janeiro, for her important studies on the Itaboraian ungulates, as well as on the geology and age of Itaboraian mammals.

Horizon and locality. Itaboraí Basin, Rio de Janeiro, Brazil (Figure1); latest Paleocene-early Eocene (Itaboraian SALMA). Diagnosis. Differs from the remaining protodidelphids by the presence of StC (larger than in Guggenheimia), StB very salient labially, StD labiolingually compressed, presence of vestigial metaconule, protocone less anteriorly displaced (in relation to the paracone and StB), and absence of pre- and postprotoconal cingula.

Measurements. $\mathrm{LM} 3=4.87 \mathrm{~mm} ; \mathrm{WM} 3=3.83 \mathrm{~mm}$.

Description. The cusps are bunodont and low. The enamel is wrinkled, mainly on the distal face of the tooth. The stylar shelf is moderately reduced in relation to the talon; the StA is relatively small and is not separated from StB by a groove; StC and StD are almost fused and both are compressed labiolingually; StB is much larger, higher and most labially expanded than the other styles; no zigzag-like crest connects $\mathrm{StB}$ and $\mathrm{StD} ; \mathrm{StC}$ is slightly higher than $\mathrm{StD}$; $\mathrm{StD}$ is continues posteriorly as a blunt crest, which ends at the metastylar corner of the tooth. The ectoflexus is relatively shallow. The pre- and postparacrista are short in comparison with the post- and premetacrista; the preparacrista ends labially between StA and StB. The centrocrista is low, weak and very probably V-shaped based on the straight postparacrista and premetacrista. There is no difference in height between the stylar shelf and the talon surface. The anterolabial cingulum is
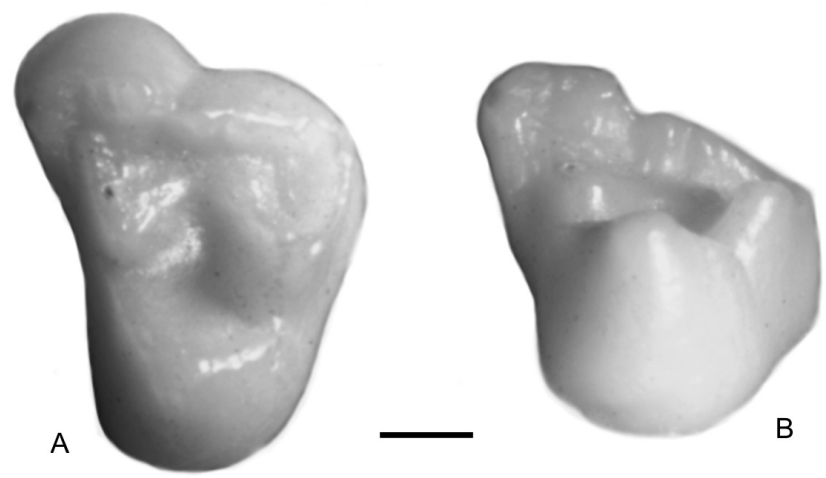

Figure 13. Periprotodidelphis bergqvistae sp. nov. (DGM 806-M, holotype), left M4. A, occlusal view; B, lingual view. Scale bar $=1 \mathrm{~mm}$. very short and oblique, and is not connected lingually with the preprotocrista. The metacone is larger in occlusal area than the paracone, but was probably equal in height. The protocone is large, tall and not eccentric. The preprotocrista is shorter and less curved than the postprotocrista. There is no trace of a paraconule. The metaconule is vestigial, virtually continuous with the labial portion of the postprotocrista, and very compressed anteroposteriorly. Only the anterolabial and lingual roots are preserved, with these being equal in size, relatively short and slightly compressed transversely.

Comments. Although in overall shape it resembles a last upper molar (M4), specimen DGM 806-M has the metacone larger than the paracone, the metastylar area is unreduced, and the tooth is not anteroposteriorly compressed. These features are compatible with those of the third upper molars of protodidelphids. General similarities are also found with the M4 of Thylacotinga bartholomaii (Archer et al., 1993). The fourth upper molar referred to T. bartholomaii by Sigé $e t$ al. (2009:816, fig. 2E) exhibits the same general morphology as the type specimen of Periprotodidelphis gen. nov., except by the metacone larger than the paracone. Thus, the molar is herein identified as a M3 because the metacone is larger than the paracone and the metastylar area is not reduced.

Periprotodidelphis bergqvistae gen. et sp. nov. shows interesting characters (symplesiomorphies?) that resemble the bunodont Paleogene marsupials Reigia and Chulpasia. Periprotodidelphis gen. nov. resembles the enigmatic Reigia in the presence of a small $\mathrm{StC}$ that is close to $\mathrm{StD}$, in the compressed metaconule, the protocone less displaced anteriorly (relative to the paracone and StB axis), the preparacrista pointing to StA and by the absence of pre- and postprotoconal cingula. However, Periprotodidelphis gen. nov. differs from Reigia in having a better developed StB and more bunoid cusps. Periprotodidelphis gen. nov. also resembles Chulpasia and Thylacontinga, which together comprise "Chulpasiinae" according Sigé et al. (2009) by the presence of StC (in Chulpasia mattaueri, but not in $C$. jimthorselli), $\mathrm{StC}$ close to $\mathrm{StD}$, low $\mathrm{StA}$, metaconule present and not displaced lingually with respect to the paracone, the protocone less anteriorly displaced, and the preparacrista pointing to StA. However, Periprotodidelphis gen. nov. differs from "chulpasiines" in having a more labially expanded $\mathrm{StB}$, a labiolingually compressed $\mathrm{StD}$, much less developed metaconule, V-shaped centrocrista (instead arch-shaped) an absence of protoconal cingula.

The phylogenetic analysis (Figures 5A,B) places Periprotodidelphis gen. nov. as the sister-taxon of Zeusdelphys and Carolocoutoia + Protodidelphis (see Phylogenetic Analysis).

\section{Genus Zeusdelphys Marshall, 1987}

1987 Zeusdelphys Marshall, p. 124.

Type species. Zeusdelphys complicatus Marshall, 1987.

Distribution. Itaboraí Basin, Rio de Janeiro, Brazil; latest Paleocene-early Eocene (Itaboraian SALMA). 
Zeusdelphys complicatus Marshall, 1987

(Figure 14)

1987 Zeusdelphys complicatus Marshall, p. 124, fig. 45.

Holotype. MCT 2830-M (ex- DGM 896a-M), a complete left ?M1.

Hypodigm. The holotype only.

Distribution. Itaboraí, Rio de Janeiro, Brazil; latest Paleoceneearly Eocene (Itaboraian SALMA).

Measurements. $\mathrm{LM} 1=8.30 ; \mathrm{WM} 1=8.47$.

Revised diagnosis. Differs from other protodidelphids in its larger size; StB and StD are very large and similar in size; StB and $\mathrm{StD}$ are labiolingually compressed and are subdivided by lateral sulci from the base to apex, mainly on StD; the enamel is strongly wrinkled; the metacone is about three times larger in occlusal area and higher than the paracone; the postmetacrista is very reduced.

Description. The molar is very large and the enamel is heavily wrinkled; the cusps are relatively low; the ectoflexus is shallow and restricted to the lingual face of $\mathrm{StD}$; the stylar shelf is very narrow, so that the base of $\mathrm{StB}$ is close to the paracone, whereas there is only a narrow area between StD and the metacone. StB and $\mathrm{StD}$ are closer to each other than are the paracone and the metacone. StB and StD are labiolingually compressed; longitudinal grooves can be observed on the lingual, mesial and distal surfaces of StD; there is no trace of $\mathrm{StC}$, although a heavily worn (or flat) central cuspule is present just lingual to the $\mathrm{C}$ position; StA is minute and placed lower than StB; the metastyle shows three small cusps, similar in size and obliquely oriented relative to the labial edge of the tooth. The premetacrista is strong, rounded and runs obliquely in relation to the anteroposterior dental axis; the postmetacrista is short and ends at the lingual face of StE; the preparacrista is rounded, ending labially to StA; the paracone is very small in relation to the metacone and to $\mathrm{StB}$ and $\mathrm{StD}$; the anterior cingulum extends lingually to the lingual face of the paracone; there is no trace of a paraconule; the metaconule is vestigial and the protocone is eccentric.

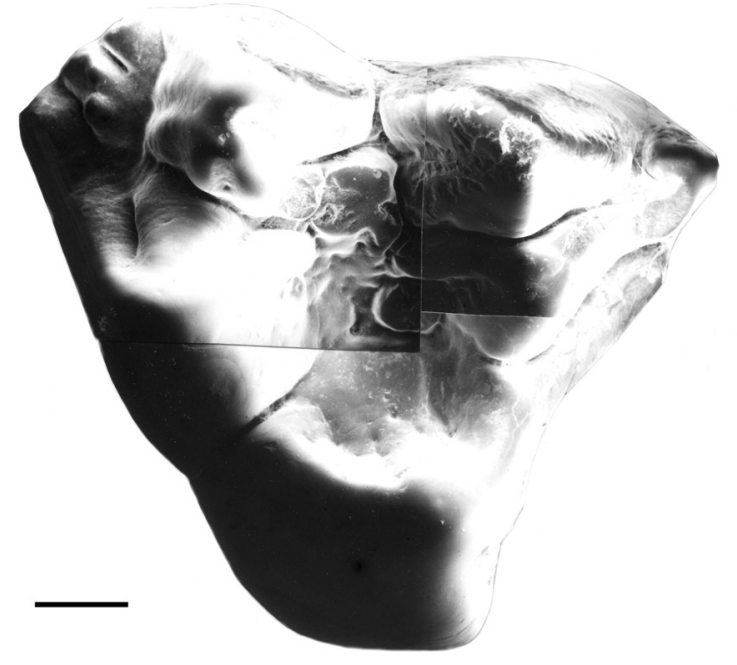

Figure 14. Zeusdelphys complicatus (MCT 2830-M, holotype), M1 in occlusal view. Scale bar $=1 \mathrm{~mm}$.
Comments. Marshall (1987) referred the same catalog number (DGM 896a-M) to the holotype of Protodidelphis mastodontoides and to that of Zeusdelphys complicatus. DGM 896a-M is retained here for the holotype of Protodidelphis mastodontoides.

As recognized by Goin et al. (1998a), the type specimen corresponds to a M1, thus explaining several features otherwise common in the M1's of other protodidelphids: small postmetacrista, StB close to the paracone, and eccentric paracone. In his original description, Marshall (1984) suggested that Zeusdelphys complicatus may represent an upper molar of Eobrasilia coutoi, a large didelphimorphian known only from the Itaboraí fauna. In spite of this interpretation, Marshall (1987) argued that the complementary structure of upper and lower dentitions of Eobrasilia and the MCT 2830-M are not structurally compatible, emphasizing that the large bulbous P2's and P3's of Didelphopsis correspond to upper molars with reduced stylar cusps, while Zeusdelphys has well developed StB and StD. However, we have identified well-developed stylar cusps in upper molars of Didelphopsis (Oliveira, 1998; Oliveira \& Goin, 2006). Goin et al. (1998a) considered that Zeusdelphys complicatus is so derived, and its known remains so scarce, that it is very difficult to precise its affinities, classifying it as Didelphimorphia incertae sedis. In absence of other specimens of this taxon, we follow Marshall (1987) regarding it as a valid taxon.

Goin et al. (1998a) commented that in Zeusdelphys the centrocrista is open, missing the point of union (centrocrista apex) between the postparacrista and the premetacrista. The situation in Zeusdelphys is similar to the condition seen in Hatcheriformes (e.g. Hatcheritherium) where the premetacrista connects to the apex of a cuspule lingual to $\mathrm{C}$ position. The premetacrista in Zeusdelphys runs obliquely in relation to the anteroposterior dental axis, as in most didelphimorphians with V-shaped centrocristae and in polydolopimorphians with open centrocristae, in contrast to the rectilinear centrocrista of peradectians and microbiotherians. However, Z. complicatus is excluded from Polydolopimorphia because of its narrower protocone, absence of metaconule and because $\mathrm{StB}$ and StD not transversely twinning with the para- and metacone, respectively.

In our phylogenetic analysis, Z. complicatus is placed within Protodidelphidae as the sister-taxon to Protodidelphis and Carolocoutoia (Figures 5A,B).

\author{
Supercohort MARSUPIALIA Gill, 1872 \\ Order DIDELPHIMORPHIA Gill, 1872 \\ Superfamily PERADECTOIDEA Marshall, Case \& \\ Woodburne 1990 \\ Family CAROLOAMEGHINIIDAE Ameghino, 1901
}

Genus Procaroloameghinia Marshall, 1982

1982 Procaroloameghinia Marshall, p. 711.

1987 Procaroloameghinia Marshall, p. 118.

2006 Procaroloameghinia Goin, p. 61.

Type species. Procaroloameghinia pricei Marshall, 1982.

Distribution. Itaboraí Basin, Rio de Janeiro, Brazil; Las Flo- 
res, Central Patagonia, Argentina; latest Paleocene-early Eocene (Itaboraian SALMA).

\section{Procaroloameghinia pricei Marshall, 1982}

(Figures 15A-E)

1982 Procaroloameghinia pricei Marshall, p. 711, figs. 1a-c. 1987 Procaroloameghinia pricei Marshall, p. 118, fig. 33. 2006 Procaroloameghinia pricei Goin, p. 61.

Holotype. DGM 805-M, fragment of a right dentary with alveoli of c1-p2 and complete p3-m2, and DGM 924-M, a fragment of the same right dentary as DGM 805-M (i.e. both specimens belong to the same individual) with complete m3-4.

Hypodigm. The type only.
Locality and age. Itaboraí, Rio de Janeiro State, Brazil. Itaboraí Basin, latest Paleocene-early Eocene (Itaboraian SALMA). Measurements. $\mathrm{Lp} 3=2.3 ; \mathrm{Wp} 3=1.7 ; \mathrm{Lm} 1=2.4 ; \mathrm{Wm} 1=2.3$; $\mathrm{Lm} 2=2.8 ; \mathrm{Wm} 2=2.3 ; \mathrm{Lm} 3=2.7 ; \mathrm{Wm} 3=2.4 ; \mathrm{Lm} 4=2.6 ; \mathrm{Wm} 4=$ 1.8 .

New diagnosis. Differs from other caroloameghiniids in being smaller than Caroloameghinia mater and larger than $C$. tenuis; the dentary is low (very high in Caroloameghinia); lower molars have trigonids higher than talonids; postprotocristid connected to the metacristid; hypoconulids are less developed; entoconids not anteriorly displaced; talonids lack enamel wrinkles.

Revised description. The dentary is relatively short, strong and low (Figures 15 A-B); its ventral edge is convex, with the maximum height below $\mathrm{m} 2-3$; the symphysis extends
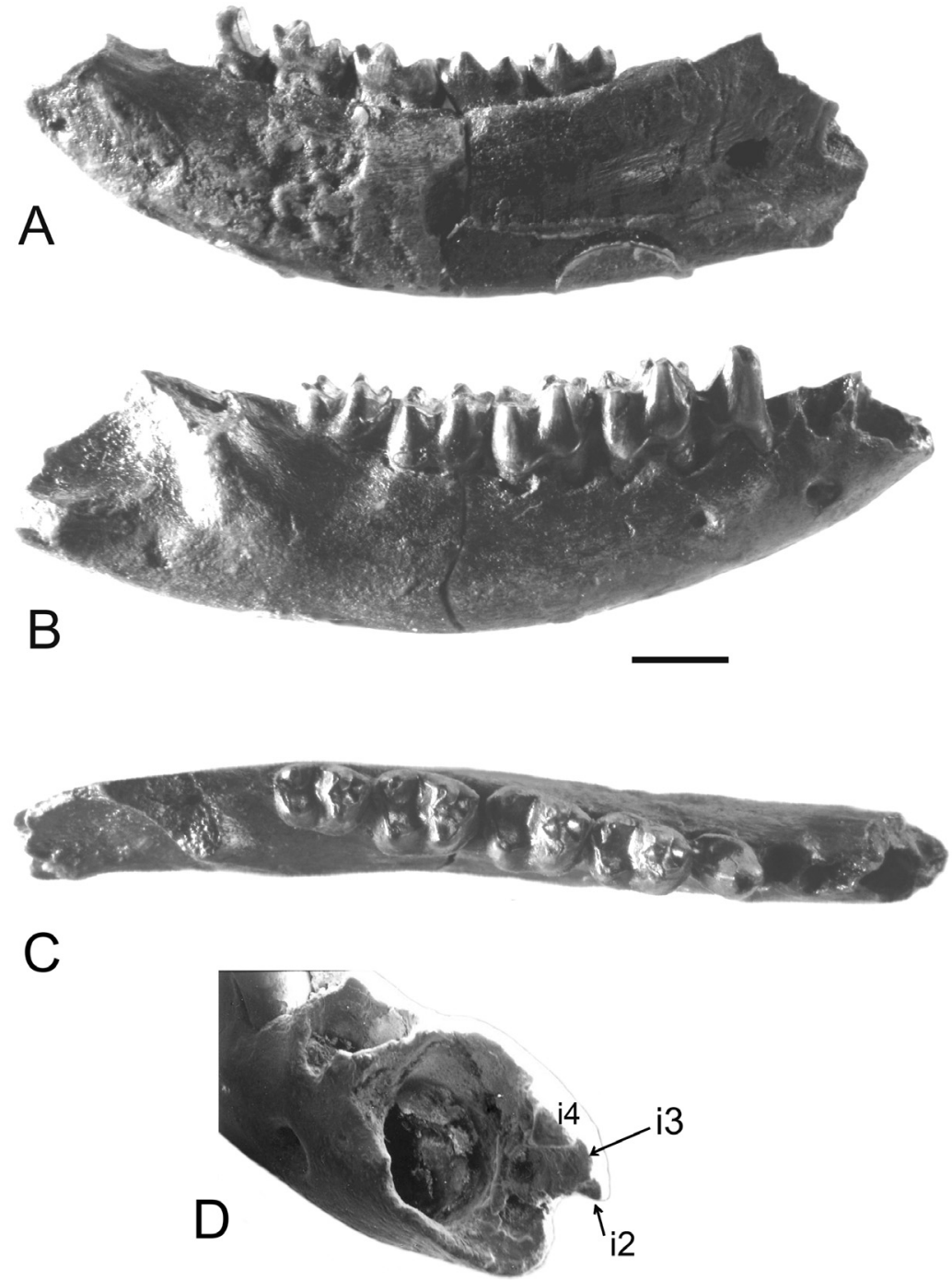
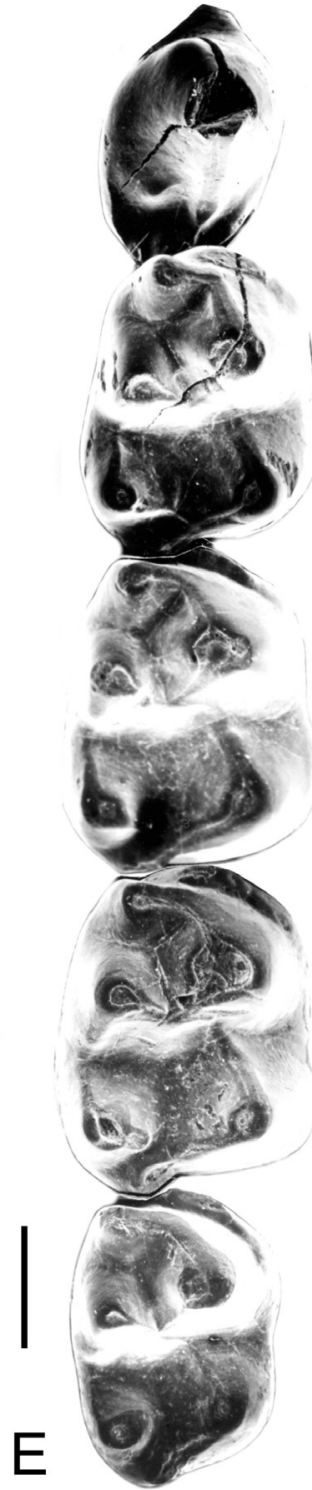

Figure 15. Procaroloameghinia pricei (DGM 805 and 924 M, holotype). A, dentary in lingual view; B, dentary in labial view; C, dentary with alveoli of canine and p1, and complete p3-m4 in occlusal; D, detail of the canine and incisor regions; $\mathbf{E}$, p3-m4 in occlusal view. Scale bars: $\mathrm{A}-\mathrm{C}=3 \mathrm{~mm} ; \mathrm{E}=1 \mathrm{~mm}$. 
posteriorly at a point below p3; two mental foramina are located below and between $\mathrm{p} 2$ and the anterior face of $\mathrm{m} 1$. Judging from the interalveolar septum that separates the incisors (Figure 15D), we identified the location of the alveoli of i2, i3 (probably was staggered) and i4. Taking into account the size and position of the alveoli, the pattern resembles that of living and fossil didelphimorphians. Regarding the premolars, p1 is single rooted, while p2 and p3 are two-rooted. Judging from its alveolus, p1 was small and laterally compressed; p2 was slightly smaller than p3; p3 is well developed, ovate in outline, and with an inflated crown; its main cusp equals in height the trigonid of $\mathrm{m} 1$, and bears a salient anterior cuspid and a distally extended posterobasal heel. All molars are bunodont, with the trigonid higher than the talonid; the protoconid is well developed, with convex lateral faces and inflated bases, being very salient labially (Figure 15E). The paraconid is moderate in size, and anterolabially displaced; the metaconid is placed slightly posterior to the protoconid; the pre- and postprotocristid are equal in size; the anterior cingulid is short and narrow. The talonid is short, subequal in width and slightly shorter than the trigonid; the entoconid is large and ovate in outline; its distal face is slightly compressed; the preentocristid is very short, though slightly longer than the postentocristid; the postentocristid is oriented transversely to the dental axis, and is not connected to the hypoconulid; the hypoconid has a wide base and is slightly compressed labiolingually; the hypoconulid is small, low, and located on the posterior margin, close to the posterolabial face of the entoconid; the cristid obliqua ends anteriorly very close to the postprotocristid notch; the posthypocristid is not transversely oriented with respect to the dental axis, but is instead oblique to it; there is no vestige of a postcingulid. The $\mathrm{m} 2$ differs from the $\mathrm{m} 1$ in that the paraconid is more anteroposteriorly compressed, the anterior cingulid is more developed, the talonid is slightly wider, the hypoconulid is slightly less developed and the trigonid is more compressed anteroposteriorly. The $\mathrm{m} 3$ differs from m1-2 in having the paraconid very compressed anteriorly; the metaconid placed closer to the paraconid, so that it forms a small basin on the trigonid; the anterior cingulid is somewhat more developed; the hypoconid is slightly more anteriorly placed than the entoconid; the preentocristid is slightly oblique in relation to the anteroposterior dental axis. The $\mathrm{m} 4$ has the trigonid small but equal in size to that of $\mathrm{m} 3$; it differs from $\mathrm{m} 3$ in having the talonid transversely narrower that the trigonid.

Comments. Procaroloameghinia pricei was recognized on the basis of two incomplete dentary pieces, both belonging to the same individual (DGM 805-M and DGM 924M). At the moment, no other material belonging this species has been found in the marsupial collections of MCN/FZBRS, MCT and MN. Goin et al. (1998a) described and figured an upper molar of Procaroloameghinia from the Itaborian Las Flores locality, Argentina, which is approximately subquadrangular in outline, exhibits a large StB and StD, well-developed StC, linear centrocrista, very long postmetacrista, metacone slightly more robust and higher than the paracone, distinct conules and a protocone that is wide anterposteriorly.

Marshall (1982b, 1987), did not comment on the incisive morphology of Procaroloameghinia, which is here described. The most interesting aspect is the identification of a pattern similar to that of didelphimorphians with staggered incisors. Taxa with very bunodont dentitions, such as that seen in $P$. pricei (which was most probably of frugivorous feeding habits) have been subject to contrasting systematic interpretations (see Phylogenetic Analysis).

\author{
Cohort AUSTRALIDELPHIA Szalay, 1982 \\ Order POLYDOLOPIMORPHIAAmeghino, 1897 \\ Family indeterminate \\ Genus Bobbschaefferia Paula Couto, 1970
}

1952b Schaefferia Paula Couto, p. 12, nec Absolon, 1900 (Collemb.), nec Houlbert, 1918 (Lepidoptera).

1962 Schaefferia Paula Couto, p. 150.

1970 Bobbschaefferia (Paula Couto), p. 20.

1987 Bobbschaefferia (Paula Couto) Marshall, p. 97.

Type species. Bobbschaefferia fluminensis (Paula Couto, 1952).

Distribution. Latest Paleocene-early Eocene (Itaboraian SALMA).

Comments. In the original description of Bobbschaefferia ("Schaefferia") fluminensis, Paula Couto (1952b) included the specimen DGM 314-M (herein described as Guggenheimia crocheti sp. nov.) as the paratype. Crochet (1980) discussed differences between the type and the paratype. Reig et al. (1987) regarded Bobbschaefferia as a possible member of Peradectidae, Superfamily Microbiotherioidea, Suborder Didelphimorphia. Marshall (1987) placed Bobbschaefferia within Protodidelphinae, Family Caroloameghiniidae, Suborder Polydolopimorphia, and suggested that Bobbschaefferia represents the most generalized caroloameghiniid known. Marshall et al. (1990) regarded Bobbschaefferia, together with Guggenheimia, Procaroloameginia, Protodidelphis and "Robertbutleria" (see above) as members of Protodidelphidae, Superfamily Polydolopoidea, Order Polydolopimorphia. Woodburne \& Case (1996) compared Bobbschaefferia with Tingamarra porterorum, from the Eocene of Murgon (Queensland), Australia, concluding that the Australian species is a marsupial with a similar derived morphology regarding the Protodidelphidae. R. Cifelli (pers. comm. to EVO) suggests a strong similarity between Bobbschaefferia and the type specimen of Tingamarra porterorum. Bond et al. (1996) and Goin et al. (1997) discussed the discovery of lower and upper molars identified as a new species of Bobbschaefferia from the Las Flores Formation, Argentina. Oliveira \& Goin (2003) regarded Bobbschaefferia as a microbiotherian, specifically within the family Glasbiidae. Glasbiids were posteriorly regared as basal polydolopimorphians (e.g. Goin \& Candela, 2004; Case et al., 2005). 
Bobbschaefferia fluminensis (Paula Couto, 1952)

(Figures 16 A-B)

1952b Schaefferia fluminensis Paula Couto, p. 13, fig. 4. 1962 Schaefferia fluminensis Paula Couto, p. 150, fig. 7. 1970 Bobbschaefferia fluminensis (Paula Couto), p. 21. 1987 Bobbschaefferia fluminensis (Paula Couto) Marshall, p. 97, fig. 3.

Holotype. MNRJ 1350-V, an incomplete left dentary with p2-3 and complete $\mathrm{m} 3-4$, roots of $\mathrm{p} 1$, roots of $\mathrm{m} 2$ and alveoli of $\mathrm{i1-}$ $3, \mathrm{C}$, and $\mathrm{m} 1$.

Hypodigm. Only the type (see below).

Horizon and locality. Itaboraí Basin, Rio de Janeiro, Brazil (Figure1); latest Paleocene early-Eocene (Itaboraian SALMA). Measurements. MNRJ 1350-V. Lp2=2.60; Wp2=1.51; Lp3= 2.61; Wp3=1.70; Lm3=3.35; Wm3=2.33; Lm4=3.11; Wm4= 1.98 .

Diagnosis. Differs from other hatcheriforms (Glasbius, Hatcheritherium and Palangania) in having a larger paraconid relative to the metaconid, narrower talonid in $\mathrm{m} 3$, absence of labial cingulid and in that the entoconid is ovate (not conical) in outline.

Revised description. Premolars include a small p1, which is set apart from p2 by a small diastema; p2 and p3 have very high crowns, inflated and with poorly developed posterobasal heels; p3 is slightly better developed than p2. Judging from the size of their alveoli, $\mathrm{m} 1$ was smaller than $\mathrm{m} 2$, and $\mathrm{m} 2$ was comparable in size to $\mathrm{m} 3$. The third molar has low, inflated cuspids. The trigonid is equal in length to the talonid and has moderately tall cuspids; the paraconid is displaced anterolabially so that the first half of the preprotocristid is oblique to the transversal dental axis. The preprotocristid and the postprotocristid are symmetrical in occlusal view. The anterior cingulid is relatively wide and runs inclined on the anterolabial corner of tooth. The talonid is equal in width

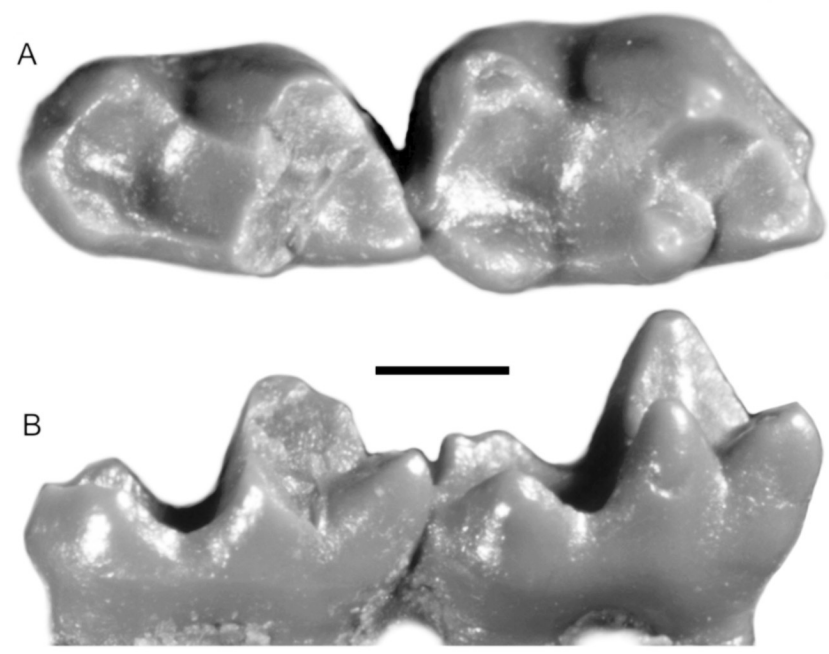

Figure 16. Bobbschaefferia fluminensis (DGM 314-M, holotype), left m3-m4. A, occlusal view; $B$, lingual view. Scale bar $=1 \mathrm{~mm}$. to the trigonid. The cristid obliqua ends anteriorly at a point labial to the postprotocristid notch. The posthypocristid is oblique to the transversal dental axis. The entoconid is tall, ovate in outline; labiolingually compressed and borders the lingual margin of the talonid. The hypoconulid is globose and is placed on the posterior margin, labial to the hypoconid. The postcingulid is poorly developed. The $\mathrm{m} 4$ differs from $\mathrm{m} 3$ in being smaller, the paraconid is stronger and in that the lingual border of the talonid is more obliquely oriented in relation to the anteroposterior dental axis. The first incisor (i2) is the largest lower incisor and, apparently, the most procumbent; judging from the alveoli walls, the roots were convex labially and planar lingually; the second alveolus (i3), is equally high, but more compressed than the alveolus of i2, with planar labial and lingual faces; this alveolus is not staggered relative to i2 and i4; the next alveolus (that of i4), is somewhat wider, mainly on its inferior border; the alveolus of i5 is close to canine; although the depth is the same, i5 is slightly smaller than the remaining alveoli.

Comments. Paula Couto (1952b) referred specimens DGM 314 M and DGM 315-M to the hypodigm of Bobbschaefferia; later (Paula Couto, 1970), he also referred MNRJ 2899-V, DGM 651-M and DGM 652-M to this taxon. As suggested by Crochet (1980), DGM 314-M belongs to Guggenheimia (see above) as does DGM 315-M (Paula Couto, 1962:152, figs. 8d-f).

\section{aff. Bobbschaefferia sp. (Figures 17A-C)}

Referred specimens. MCN-PV 1797, an incomplete right maxilla with M2, alveolus of M3 and partial alveoli of M4; MCT 2816-M, a complete right M3.

Measurements. MCN-PV 1797: LM2=2.70; WM2=2.50. MCT 2816-M: LM3=2.90; WM3=2.55.

Description. The M2 (MCN-PV 1797; Figure 17A) has low and poor inflated cusps; the stylar shelf is moderately narrow; all the stylar cusps are present, with StB being the largest stylar cusp, equal in size to the paracone; StB and StD are set apart and are the largest stylar cusps; StD is compressed and connected to $\mathrm{StC}$ by a low crista; $\mathrm{StB}$ is connected to $\mathrm{StC}$ by a labial crest; StA is small and low; StD is minute. The ectoflexus is moderately deep. Strong wear occurs on the preparacrista and the postmetacrista. The preparacrista ends labially between the StB and StA. The centrocrista is linear (arch-shaped), low and with the postparacrista more clearly marked than the premetacrista. The anterior cingulum is very narrow and lingually continuous until it reaches the preparaconular crista. The metacone is slightly higher than the paracone. Both the paracone and the metacone are anteroposteriorly compressed. The protocone is wide and centrally placed. The metaconule is much better developed than the paraconule; the metaconule and the paraconule are not close to the bases of the metacone and paracone, but are instead slightly lingually placed. 
The M3 (MCT 2816-M; Figures 17B-C) differs from the $\mathrm{M} 2$ in having a deeper ectoflexus, and in that StA is more robust anterolabially. In this tooth the stylar cups are sharp and the conules are winged. The posterior cingulum is short and very narrow.

Comments. The teeth are smaller than the size expected for the upper molars of Bobbschaefferia fluminensis. However, their occlusal relationships are compatible taking in account the hypoconid-talonid outline, the centrocrista shape and talon basin. This new material is regarded as aff. Bobbschaefferia based on comparison with undescribed materials of this genus from the Las Flores Formation (Goin et al., 1997), Argentina, and by exclusion of Mirandatherium, a closely related genus. Mirandatherium has been identified as a microbiotherian based on the presence of low cusps, a posteriorly displaced metaconid relative to the protoconid, and talonids wider than trigonids. Thus, expected upper molars of Mirandatherium should be microbiotheriid-like instead of glasbiid-like. Paleogene microbiotherians, as exemplified by Woodburnodon (Goin et al., 2007) and perhaps Khasia (Muizon, 1991; but see Oliveira \& Goin, 2006) have upper molars with reduced stylar cusps, linear centrocrista, and reduced conules. The molars herein described have relatively large and quite widely separated $\mathrm{StB}$ and $\mathrm{StD}$, well developed $\mathrm{StC}$, linear centrocrista, protocone wide and large, and lingually displaced metaconule. All these features are more compatible with those of glasbiids (Hatcheriformes) than with those of microbiotherians (Microbiotheria).

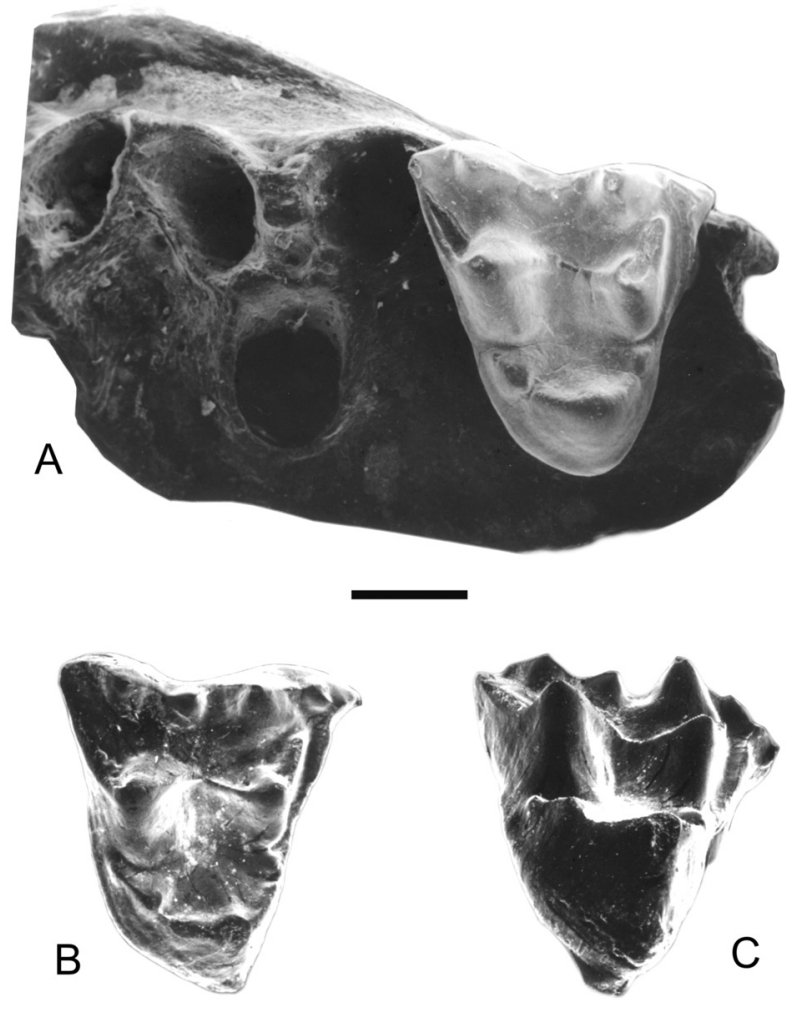

Figure 17. aff. Bobbschaefferia sp. A, (MCN-PV 1797), right maxilla in occlusal view; B, (MCT 2816-M), right M3 in occlusal view; C, (MCT 2816-M), right M3 lingual view. Scale bar $=1 \mathrm{~mm}$.

\section{PHYLOGENETIC ANALYSIS}

Twenty most parsimonious tree resulted from a heuristic search of 30 taxa and 74 characters, with a length of 276 steps, ensemble consistency index (CI) of 0.4565 and ensemble retention index (RI) of 0.7253 (Figure $5 \mathrm{~B}$ ). The results of a 1000 replicate bootstrap search of the data matrix, with only support values of $>50 \%$ indicated, is shown in Figure $5 \mathrm{~A}$. One of the main purposes of this analysis was to test the hypothesis that all bunodont taxa from Itaboraí belong to a natural group at the ordinal level. As shown in Figures 5A-B, they do not. In the consensus tree Procaroloameghinia is placed as the sister taxon to microbiotherians + polydolopimorphians and ameridelphians, Bobbschaefferia and Mirandatherium are grouped within the Australidelphia, and Carolocoutoia, Guggenheimia, Protodidelphis, Zeusdelphys and Periprotodidelphis are grouped within the Protodidelphidae. In the absence of a more comprehensive analysis of Cenozoic and living "opossum-like" metatherians, we have listed most the bunodont taxa here analyzed as "Ameridelphia" incertae sedis. Although the analysis was restricted to dental characters and a reduced number of taxa, a series of interesting groupings of several of the bunodont (and non bunodont) taxa of Itaboraí can be identified. In the following sections we discuss the most noteworthy of them. The most plesiomorphic ingroup taxa in the analysis is the hathlyacinid Patene. This basal position of Patene is consistent with previous studies of Oliveira (1998), Goin (2003), Oliveira \& Goin (2006) and Ladevèze \& Muizon (2010), which excluded it from the "Didelphimorphia" or the crowgroup Marsupialia. Goin (2003) suggested that the molar morphology of Patene (and also of Mayulestes from Tiupampa, Bolivia) presents protocones and talonids only slightly reduced, paracone and metacone twinning incomplete (i.e. the paracone and the metacone are not coalescent at their bases), stylar cusps are moderately developed, the preparacrista is not reduced in length, the postmetacrista is only moderately enlarged, and, together with the paracristid, is quite transversal to the dental axis; in the lower molars, the paraconid is not reduced or shifted antero-medially, and hypoconulids are high. This combination of features is characteristic of peradectids (i.e. Peradectinae sensu Korth 1994; but see below), of which Patene and Mayulestes may constitute a derived lineage of carnivorous or faunivorous feeding habits.

\section{Affinities of Procaroloameghinia}

Procaroloameghinia is placed as the sister taxon of two large clades composed by polydolopimorphians + microbiotherians, and Paleogene opossums and living marsupials. Marshall (1982a) and later Marshall (1987) compared Procaroloameghinia with Caroloameghinia, from the Casamayoran of southern Argentina, regarding Procaroloameghinia as directly ancestral to Caroloameghinia. 
Reig et al. (1987) classified Procaroloameghinia as a member of Caroloameghiniidae within Didelphimorphia. Marshall et al . (1990) classified Procaroloameghinia as a member of Protodidelphidae, within Polydolopimorphia. Muizon (1991) and Muizon \& Brito (1993) regarded Procaroloameghinia and Caroloameghinia as members of the family Peradectidae, within Peradectia. Archer et al. (1993) emphasized that Procaroloameghinia is not certainly a caroloameghiniid and Ladevèze \& Muizon (2010) consider it as a member of Protodidelphidae, which also includes Didelphopsis. An upper molar from the Las Flores locality, Central Patagonia, Chubut province, Argentina referred by Goin et al. (1998a) to Procaroloameghinia, was the first step in recognizing the peradectoid affinities of this marsupial. Goin (2006) argued against the microbiotherian or polydolopimorphian affinities of Caroloameghiniidae, stating instead that: (i) they are part of the peradectoid radiation, and (ii) a new phylogenetic analysis should test the hypothesis that peradectoideans are indeed didelphimorphians. Our analysis of the available material from Itaboraí and Patagonia, as well as the phylogenetic analysis in this paper, suggest that Procaroloameghinia is a basal metatherian with bunoid dentition convergent with, but without direct affinities to, protodidelphids and polydolopimorphians. Notwithstanding, recent analyses by Horovitz et al. $(2008,2009)$ including several sources of (mostly cranial) morphological characters, argue in favour of a sister-group relation between peradectoids and didelphoids (their Didelphimorphia). Taking in account these evidences we provisionally follow this last concept of Didelphimorphia (see Appendix 1).

\section{Protodidelphidae and closely related taxa}

The phylogenetic analysis supports the sistergroup relationships of Protodidelphidae with other Paleogene "opossum-like" methaterians, the Australian Djarthia and living marsupials. Derived characters supporting this relationship include a V-shaped and very invasive centrocrista (16.2), moderately developed centrocrista (17.1), moderately higher stylar shelf relative to trigon basin (19.1), flat to concave labial faces of paracone and metacone (25.1), much larger metacone relative to paracone (26.2), lingual face of metacone clearly lingual in relation to that of the paracone in M2 or M3 (27.1), narrow protocone (29.0), preparacrista pointed at, or connected with StB (34.0), and presence of staggered lower incisor (73.1).

The protodidelphids (node D) are grouped by characters such as the presence of shallow ectoflexus in M2-3 (4.2), only StB and StD most developed (5.3), StB and StD close to each other (8.1), reduced or lost StC (9.2), vestigial or absent metaconule (21.2), eccentric protocone in M1-2 (30.1), abrupt increasing size from $\mathrm{M} 1 / \mathrm{m} 1-\mathrm{M} 3 / \mathrm{m} 3$ (43.0), subequal to slightly smaller M4/m4 in relation to $\mathrm{M} 3 / \mathrm{m} 3$ (44.0), massive entoconid, occuping most of the talonid (54.3), hypoconid equal to entoconid in size (64.1), and posthypocristid extends farther lingually (67.1). Goin et al. (1998a) discussed the possibilities that Guggenheimia, one of the most plesiomorphic protodidelphids then described, was probably not a member of this family, taking in account several features present in undescribed specimens of this genus from Las Flores, Argentina. Our phylogenetic analysis places Guggenheimia as the most basal protodidelphid. The plesiomorphic condition of Guggenheimia is suggested by a less bunoid dentiton than do other known protodidelphid, the postmetacrista is more developed, and a minute $\mathrm{StC}$ is present. However, it is important to observe that on the M1 of the type of Protodidelphis, the general molar pattern is the same as that seen in Guggenheimia: the protocone is eccentric (anteriorly displaced), and the postmetacrista is relatively well developed. Another interesting character of Guggenheimia is the "staggered" condition of the second lower incisor (or i3 of Hershkovitz, 1982; fig. 13B), which is suggestive of a closer relationship with several basal, "ameridelphian" clades rather than to polydolopimorphian or microbiotherian (see also Goin et al., 1998a; Oliveira, 1998; Oliveira \& Goin, 2006). The lower incisors in most didelphids are subequal in size, except i2 and i5 (Takahashi, 1974). In Guggenheimia the second incisor is larger than $\mathrm{i} 2$ and i4, a feature probably related to the staggered condition. Hershkovitz $(1982,1995)$ has suggested that five lower incisors were originally present in marsupials, and that the reduction of the anterior part of the jaw resulted in the loss of i1. Interestingly, a staggered incisor is also present in derorhynchids from Itaboraí (Paula Couto, 1962; Oliveira \& Goin, 2006) and in herpetotheriids (Fox, 1983; Goin \& Candela, 2004). These taxa have been argued to be related (Goin, 1991, 2003) and may represent a monophyletic group that greatly diversified in the early Paleogene of South America. According to Goin \& Candela (2004) the presence of an enlarged second incisor occurs in several specimens belonging to different species reviewed by Crochet (1980), including Amphiperatherium minutum, A. ambiguum, and Peratherium perrierense (see Crochet, 1980, figs. 87a,b, 129, $217,232)$. The most notable circumstance is that the differences in the relative sizes of the lower incisors among South American didelphids have only been recorded in Paleogene metatherians such as the Itaboraian Derorhynchus (Paula Couto, 1962; Marshall, 1987) and Eobrasilia (Marshall, 1984). Our phylogenetic analysis supports a sister taxon relationships between Peratherium and Derorhynchus, in a clade composed also by Carolopaulacoutoia and the Australian Djarthia, which in turn is the sistergroup of Itaboraidelphys + Didelphopsis.

It is still not clear whether the "staggered" pattern, as suggested by Hershkovitz (1982, 1995), was a single event in the evolutionary history of metatherians, or, alternatively, happened several times in different, non-related clades. Many comparative studies have been made only with living specimens (e.g. Recent didelphids). In the scarce fossil specimens that preserve the anteriormost portion of their dentaries, the best way of evaluating this feature seems to be from an antero-labial view (as suggested by Hershkovitz, 1995). In some taxa such as Guggenheimia, an undescribed derorhynchid from Itaboraí and in some herpetotheriids (Oliveira, 1998; Goin \& Candela, 2004) a noticeable feature is the enlargment of the second lower incisor (i3). As see above, 
the review of the incisive region of Procaroloameghinia suggests the probable presence of a staggered alveolus. Interestingly, the non-staggered condition is present in Bobbschaefferia (Peradectia; Oliveira, 1998).

On the basis of dental synapomorphies (utilizing upper and lower dentition) Ladevèze \& Muizon (2010) suggested a sister-group relationship between Guggenheimia and Mirandatherium, which composed the sister-group to Marsupialia. In the present paper this relationships is not supported. Caution is need when the upper dentition of Mirandatherium is utilized in phylogenetic studies. The upper molars (MNRJ 2506-V) referred to Mirandatherium by Marshall (1987) and Oliveira (1998) actually belong to Derorhynchus (see Goin et al., 2009). Marshall (1987) first considered Mirandatherium to be a Microbiotheriidae and later Marshall et al. (1990) classified it as a Didelphidae. In this paper we regard Mirandatherium as a member of Microbiotheriidae (see below). Herein, the living marsupials (node C) compose a polytomy along with Pucadelphys, Marmosopsis and a clade including Szalinia, Gaylordia, Tiulordia, Monodelphopsis and Minusculodelphis.

Ladevèze \& Muizon (2010) included Zeusdelphys, along with Minusculodelphis and the problematical Monodelphopsis within Australidelphia Eometatheria. Monodelphopsis was redefined by Marshall (1987) to include several referred materials, including MNRJ 2354-V and DGM $808-\mathrm{M}$, which is composed by upper molars. However, Oliveira (1998) and Oliveira \& Goin (2006) have excluded these materials from the hypodigm of Monodelphopsis as well as other materials, maintining only the type (DGM 652-M) and MNRJ 2340-V, which include only information on lower dentition. Thus conclusions based on materials as defined by Marshall (1987) are highly problematicals. Minusculodelphis is currently under study by us and the present phylogenetic analysis supports a closer relationship with Monodelphopsis, but as members of a clade composed by Tiupampan taxa (Pucadelphys and Szalinia), Itaboraian (Marmosopsis, Gaylordia) and living didelphids. Regarding Zeusdelphys our results differs from that of Ladevèze \& Muizon (2010). In our analysis no closer relationship was found between Zeusdelphys with Minusculodelphis and/or Monodelphopsis. The type materials of these taxa are not comparable because Zeusdelphys is based on an upper molar and Minusculodelphis and Monodelphopsis are based on lower dentitions. Of the eleven synapomorphies defining the Protodidelphidae at least four are present in Zeusdelphys: shallow ectoflexus in M2-3 (4.2), only StB and StD most developed (5.3), StB and StD close to each other (8.1), reduced or lost StC (9.2), and eccentric protocone in M1-2 (30.1).

The origin of Protodidelphidae is currently unknown. An early origin of this group, perhaps as early as the early Paleocene or even the Maastrichtian, should not be rejected. Within the context of latest Cretaceous marsupials, it is noteworthy that some features relate protodidelphids with quite early forms, such as "Alphadon" eatoni from the Maastrichtian of Utah in North America (Cifelli \& Muizon, 1998). These authors noted that " $A$ ". eatoni is primitive in lacking a staggered pattern in the lower incisors, but remarked on the enlarged condition of the second lower incisor (i2 of Cifelli \& Muizon, 1998). In addition, Alphadon eatoni is dentally similar to Guggeinhemia in having the paraconid reduced relative to metaconid and situated less lingually (anterolabially displaced) than the metaconid, the cristid obliqua intersecting the back of the trigonid below the postprotocristid notch and the entoconid is conical (not blade-like). An alternative hypothesis regarding the origin of Protodidelphidae is that representatives of this family had their origins and rapid radiation as a response of the hyperthermal events that occurred in the latest Paleocene and early Eocene [Late Paleocene Thermal Event (LPTM), and Early Eocene Climatic Optimum (EECO), respectively]. Our referral of the Itaboraian SALMA to this time period agrees well with this last assumption. Protodidelphids were originally known only from Itaboraí, Brazil. At present, no protodidelphid or related taxa has been reported for the early Paleocene of Tiupampa (Bolivia), or for the mid-Paleocene Peligran fauna of Patagonia. It is interesting to note that during the latest Paleocene and early Eocene, protodidelphids (as well as derorhynchids, caroloameghiniids and sternbergiids) are also recorded in the Las Flores Formation, Patagonia, and in the La Barda locality, central-western Patagonia (Tejedor et al., 2009). This suggests the presence of extensive tropical environments throughout much of the South American territory. The abundance of frugivorous/omnivorous taxa, such as those represented by Protodidelphidae, together with their absence in earlier assemblages (Tiupampian and Peligran faunas), suggests a radiation that was contemporary with the already mentioned hyperthermal events.

\section{Affinities of Bobbschaefferia}

Bobbschaefferia was originally recognized on the basis of lower molars; later, Oliveira \& Goin (2003:828, fig. 12B) identified an upper molar of a glasbiid in the Itaboraí fauna, which is herein identified as aff. Bobbschaefferia (see above). In the phylogenetic analysis presented here, this taxon is related to polydolopimorphians (node B), as they share $\mathrm{StC}$ positioned close to $\mathrm{StD}$ (11.3), lingually displaced metaconule (22.1), postmetacrista about equal to preparacrista (35.0), postprotocrista extends labially past metacone (double rank postvallum/prevallid shear (38.1), obtuse angle between pre\& postprotocristae (39.2), abrupt increasing size from M1/ $\mathrm{m} 1-\mathrm{M} 3 / \mathrm{m} 3$ (43.0), reduced posterior cingulum (45.0), about equal width of trigonid relative to talonid (51.1.), paraconid about equal to metaconid (56.0), anteromedially located paraconid (57.1), hypoconulid terminal in position, not twinned with the entoconid (62.0), posthypocristid extends farther lingually (67.1), and large size judging from dentition (74.1). This phylogenetic relationship is in disagreement with that suggested by Marshall et al. (1990), which Bobbschaefferia is regarded as a member of Protodidelphidae or with that of Ladeveze \& Muizon (2010) where it is regarded as a member of Boreometatheria. Interestingly, in Bobbschaefferia the incisive alveolar morphology lacks the staggered pattern, in sharp contrast with "polyprotodont" 
metatherians (Oliveira, 1998; Oliveira \& Goin, 2006). Case et al. (2005) included within the polydolopimorphian clade Hatcheriformes the North American Hatcheritherium and Glasbius, and from South America the genus Palangania (but see Beck et al., 2008). Herein Bobbschaefferia is regarded as a basal polydolopimorphian, even though the scarce evidence at hand prevents us from assign it to any particular family of this order. Within it, aff. Bobbschaefferia is clearly one of the most plesiomorphic taxa in having an only moderately reduced stylar shelf, well developed StC, complete centrocrista and persistence of the posterior cingulum. We note that aff. Bobbschaefferia is quite similar to the Late Cretaceous, North American Hatcheritherium (Case et al., 2005) in, for example, the size relation between the paracone and the metacone, relative size of the stylar cusps, shape of the protocone, and position of the metaconule. Case et al. (2005) suggested that the Polydolopimorphia originated in the latest Cretaceous of North America and then dispersed to South America (via the Caribbean region). However, the plesiomorphic condition of aff. Bobbschaefferia requires that this hypothesis be treated with caution, pending the discovery of Late Cretaceous and early Paleocene marsupials in tropical South and Central Americas.

Another interesting aspect to be considered are the striking similarities between Bobbschaefferia and the Australian, early Eocene genus Tingamarra (see also Woodburne \& Case, 1996). Godthelp et al. (1999) described Tingamarra as a possible placental given the presence of the hypoconulid located at the midpoint of the posterior margin and not at the corner of the talonid as in most metatherians. Pending a better comparative study between (still undiscovered) more complete specimens of Tingamarra and Bobbschaefferia, and given the striking similarities among the two taxa, a closer relationship between them should not be discarded.

Another interesting question is the sister-taxon relationships between Mirandatherium and Microbiotherium (node A), suggesting that Mirandatherium is a member of Australidelphia in the Itaboraí fauna. These results agree partially with those of Ladeveze \& Muizon (2010), which suggest that presence of australidelphian forms in Itaboraí as result of their study of petrosal bones. However, a recent analysis of selected metatherians on the basis of postcranial, petrosals and dental characters led Beck et al. (2008) to suggest that Djarthia is the oldest unequivocal member of Australidelphia, a similar position to that suggested by Wroe (2000). According to the present phylogenetic analysis, we found that Djarthia is closely related to Peratherium, Carolopaulacoutoia and Derorhynchus. The synapomorphies suggesting this relationship include only two characters: hypoconid equal to entoconid in size (64.1), and posthypocristid extends farther lingually (67.1). Another interesting character shared by these taxa is the presence of a "central cusp". This character was discussed for the Australian taxa by Godthelp et al. (1999) and reported for the first time for Itaboraian taxa by Oliveira (1998) and later by Oliveira \& Goin (2003). As emphasized by Godthelp et al.
(1999: 293) "the presence of a "central cusp" clearly distinguishes Djarthia murgonensis from all other marsupials, excepting Ankotarinja tirarensis and Keeuna woodburnei". An apparent central cusp is present in Nortedelphys, from Late Cretaceous of North America (Case et al., 2005). However, in Nortedelphys the "central cusp" at the apex of the centrocrista is the StC that is lingually displaced. Thus, this condition in Nortedelphys is distinct from that of the Australian Djarthia, Ankotarinja and Keeuna, the European Peratherium, and the South American Carolopaulacoutoia, Itaboraidelphys and Didelphopsis, in which the "central cusp" is an accessory one. Maastrichtidelphys, a taxon recently described from the Maastrichtian of Europe (Martin et al., 2005), with an accessory central cusp, has been related to the latest Cretaceous herpetotheriids of North America, a conclusion we cast doubts on. Thus, this character constitutes an unambiguous evidence of intercontinental relationships involving the above cited Itaboraian taxa, the Eocene Australian taxa Djarthia and, the early Eocene European Peratherium. The dentition data herein presented is in part congruent with the hypothesis of Ladevèze \& Muizon (2010) given the australidelphian petrosal morphotype (type IV) inferred for Carolopaulacoutoia, which is considered by these authors as a stem Australidelphia.

Turning back to Mirandatherium, a problem in this context is that the latter (as well as Bobbschafferia) is represented only by dental remains and its sister-taxon relationship with Microbiotherium in this paper is supported by only a synapomorphy: hypoconid equal to entoconid in size (64.1). Nonetheless, Goin et al. (1998b) reported the discovery of upper molars referable to the microbiotheriid Mirandatherium from the Itaboraian locality of Las Flores in central Patagonia, Argentina, that have a morphology quite different from the upper molars referred to the same genus by Marshall (1987) and Oliveira (1998). These the upper molars of Mirandatherium show reduced stylar shelf, distinct stylar cusps $\mathrm{StB}$ and $\mathrm{StD}$, which are incipiently paired with the paracone and metacone, respectively, and an enlarged metaconule, but not paraconule. We follow the position of Goin \& Candela (2004) which microbioteres (including Mirandatherium) and polydolopimorphians (including Bobbschaefferia) are grouped in an unnamed taxon within Australidelphia, together with ?diprotodonts.

\section{ACKNOWLEDGMENTS}

Special thanks to J. Ferigolo, D.A. Campos, A.W.A. Kellner and D.D. Henriques which permitted access to the marsupial collections from the Fundação Zoobotânica do Rio Grande do Sul, Porto Alegre; Departamento Nacional de Produção Mineral (DNPM), Rio de Janeiro; and Museu Nacional, Rio de Janeiro. Sincere thanks to L.P. Bergqvist, M. Gomide and E. Abrantes for cordial hospitality in Rio de Janeiro. We also extend greatitude to P.V. Nova, R.C. Silva, K.O. Porpino, A.M. Ribeiro, L. Kerber, J.M. Sayão and B.C.V. Albuquerque for assistance. M. Woodburne and R. Beck for the helpful 
corrections and suggestions to the manuscript. The photography of figures $15 \mathrm{~A}-\mathrm{C}$ was made by R.C. Silva. Support for this study was provided by CNPq (Brazil, grant number 455414/2010-6) and CONICET (Argentina).

\section{REFERENCES}

Almeida, F.F.M.de.; Carneiro, C.R. \& Mizusaki, A.M.P. 1996. Correlação do magmatismo das bacias da margem continental brasileira com o das áreas emersas adjacentes. Revista Brasileira de Geociências, 26(3):125-138.

Ameghino, F. 1894. Synoptic enumeration of the fossil mammalian species from the Eocene formations of Patagonia. Boletín de la Academia de Ciencias de Córdoba, 13:259-452.

Aplin, K.O. \& Archer, M. 1987. Recent advances in marsupial systematics with a new syncretic classification. In: M. Archer (ed.) Possums and Opossums: Studies in Evolution, Surrey Beatty \& Sons and the Royal Zoological Society of New South Wales, p. 15-72.

Archer, M. 1984. The Australian marsupial radiation. In: M. Archer \& G. Clayton (eds.) Vertebrate zoogeography and evolution in Australasia, Hesperian Press, p. 633-808.

Archer, M.; Godthelp, H. \& Hand, S.J. 1993. Early Eocene marsupial from Australia. Kaupia, 3:193-200.

Beck, R.M.D.; Godthelp, H.; Weisbecker, V.; Archer, A. \& Hand, S.J. 2008. Australia's oldest marsupial fossils and their biogeographical implications. PLoSONE, 3(3):e1858. doi:10.1371/journal.pone.0001858

Bergqvist, L.P.; Mansur, K.; Rodrigues, M.A.; Rodrigues-Francisco, B.H.; Perez, R.A.R. \& Beltrão, M.C.M.C. 2008. Itaboraí Basin, State of Rio de Janeiro - the cradle of mammals in Brazil. In: M. Winge; C. Schobbenhaus; C.R.G. Souza; A.C.S. Fernandes; M. Berbert-Born \& E.T. Queiroz (eds.) Sítios Geológicos e Paleontológicos do Brasil, CPRM, p.1-19.

Bond, M.; Carlini, A.A.; Goin, F.J.; Legarreta, L.; Ortiz-Jaureguizar, E.; Pascual, R. \& Uliana, M.A. 1995. Episodes in South American land mammal evolution and sedimentation: testing their apparent concurrence in a Paleocene succession from central Patagonia. In: CONGRESO ARGENTINO DE PALEONTOLOGÍA Y BIOESTRATIGRAFÍA, 6, 1995. Actas, Trelew, p. 47-58.

Case, J.; Goin, F.J. \& Woodburne, M. 2005. South American” Marsupials from the Late Cretaceous of North America and the Origin of Marsupial Cohorts. Journal of Mammalian Evolution, 12:461-494. doi: 10.1007/s10914-005-7329-3

Cifelli, R.L. 1993. Early Cretaceous mammal from North America and the evolution of marsupial dental characters. Proceedings National Academy of Sciences, 90:9413-9416.

Ciffeli, R.L. \& Johanson, Z. 1994. New marsupial from the upper Cretaceous of Utah. Journal of Vertebrate Paleontology, 14(2):292-295.

Cifelli, R.L. \& Muizon, C. de 1997. Dentition and jaw of Kokopellia $j u d d i$, a primitive marsupial or near-marsupial from the medial Cretaceous of Utah. Journal of Mammalian Evolution, 4:242258.

Cifelli, R.L. \& Muizon, C. de 1998. Marsupial mammal from the upper Cretaceous North Horn Formation, Central Utah. Journal of Paleontology, 72(3):532-537.

Clemens, W.A. 1966. Fossil mammals of the type Lance Formation Wyoming. Part II. Marsupialia. University of California Publications in Geological Sciences, 62:1-122.
Clemens, W.A. 1979. Marsupialia. In: J.A. Lillegraven; Z. KielanJaworowska \& W. Clemens (eds.) Mesozoic mammals: the first two-thirds of mammalian history. University of California Press, p.192-220.

Cordani, U.G. 1970. Idade do vulcanismo no Oceano Atlântico Sul. Boletim IGA, 1:9-75.

Crochet, J.-Y. 1979. Diversité systématique des Didelphidae (Marsupialia) européens tertiaires. Géobios, 12(3):365-378.

Crochet, J.-Y. 1980. Les Marsupiaux du Tertiaire d'Europe. Paris, Éditions de la Fondation Singer-Polignac, 279 p.

Crochet, J.-Y. \& Sigé, B. 1983. Les mammiferes montiens de Hainin (Paleocene moyen de Belgique) Part III: Marsupiaux. Palaeovertebrata, 13(3):51-64.

Davis, B.M. 2007. A revision of "pediomyid" marsupials from the Late Cretaceous of North America. Acta Palaeontologica Polonica, 52(2):217-256.

Estravís-Fernandez, C. 1992. Estudo dos mamíferos do Eocénico inferior de Silveirinha (Baixo Mondego). Faculdade de Ciências e Tecnologia, Universidade Nova de Lisboa, Tese de Doutorado, $248 \mathrm{p}$.

Ferrari, A.L. 2001. Evolução tectônica do Graben da Guanabara. Programa de Pós-Graduação em Geociências, Universidade de São Paulo, Tese de Doutorado, 412 p.

França, R.L.; Del Rey, A.C.; Tagliari, C.V.; Brandão, J.R. \& Fontanelli, P.R. 2007. Bacia de Mucuri. Boletim de Geociências da Petrobrás, 15(2):493-499.

Fox, R.C. 1983. Notes on the North American marsupials Herpetotherium and Peradectes. Canadian Journal Earth Sciences, 17:1489-1498.

Gelfo, J.N.; Goin, F.J.; Woodburne, M.O. \& Muizon, C. de 2009. Biochronological relationships of the earliest South American paleogene mammalian faunas. Palaeontology, 52(1):251-269. doi: $10.1111 / j .1475-4983.2008 .00835 . x$

Godthelp, H.; Archer, M.; Cifelli, R.; Hand, S.J. \& Coral, F.G. 1999. Earliest known Australian Tertiary mammal fauna. Nature, 356:514-516.

Godthelp, H.; Wroe, S. \& Archer, M. 1999. A new marsupial from the Early Eocene Tingamarra local fauna of Murgon, Southeastern Queensland: a prototypical Australian marsupial? Journal of Mammalian Evolution, 6(3):289-313.

Goin, F.J. 1991. Los Didelphoidea (Mammalia, Marsupialia) del Cenozoico tardío de la Región Pampeana. Facultad de Ciencias Naturales y Museo de La Plata, Tese de Doutorado, 327 p.

Goin, F.J. 2003. Early marsupial radiations in South America. In: M. Jones; C. Dickman, \& M. Archer (eds.) Predators with Pouches: the Biology of Carnivorous Marsupials, Commonwealth Scientific \& Industrial Research Organization, p. 30-42.

Goin, F.J. 2006. A review of the Caroloameghiniidae, Paleogene South American "primate- like" marsupials (Didelphimorphia, Peradectoidea). Palaeontographica Abteilung A, 278:57-67.

Goin, F.J. \& Candela, A.M. 1996. A new early Eocene Polydolopimorphian (Mammalia, Marsupialia) from Patagonia. Journal of Vertebrate Paleontology, 16(2):292-296.

Goin, F.J. \& Candela, A.M. 2004. New Paleogene marsupials from the Amazon Basin of eastern Peru. In: K.E. Campbell (ed.) The Paleogene mammalian fauna of Santa Rosa, Amazonian Peru, Science Series, Natural History Museum of Los Angeles, p. 15-60.

Goin, F.J. \& Oliveira, E.V. 2007. A new species of Gashternia (Marsupialia) from Itaboraí (Brazil). Neues Jahrbuch für Geologie und Paläontologie, Abhandlungen, 24:309-313. doi: 10.1127/0077-7749/2007/0245-0309 
Goin, F.J.; Candela, A.M. \& Forasiepi, A. 1997. New, middle Paleocene marsupials from Central Patagonia. In: ANNUAL MEETING OF THE SOCIETY OF VERTEBRATE PALEONTOLOGY, 57, 1997. Abstracts, New York, SVP, p. 49A.

Goin, F.J.; Oliveira, E.V. \& Candela, A.M. 1998a. Carolocoutoia ferigoloi nov. gen. and sp. (Protodidelphidae), a new Paleocene "opossum-like" marsupial from Brazil. Palaeovertebrata, 27:145-154.

Goin, F.J.; A.M. Candela; Bond, M.; Pascual, R. \& Escribano, V. 1998b. Una nueva “comadreja” (Mammalia, Marsupialia, ?Polydolopimorphia) del Paleoceno de Patagonia, Argentina. Buenos Aires, Asociación Paleontológica Argentina, p. 71-78 (Publicación Especial 5).

Goin, F.J.; Zimicz, N.; Reguero, M.A.; Santillana, S.N.; Marenssi, S.A. \& Moly, J.J. 2007. New marsupial (Mammalia) from the Eocene of Antarctica, and the origins and affinities of the Microbiotheria. Revista de la Asociación Geológica Argentina, 62:597-603.

Goin, F.J.; Candela, A.M.; Abello, M. A.; \& Oliveira, E.V. 2010. Earliest South American paucituberculatans and their significance in the understanding of 'pseudodiprotodont' marsupial radiations. Zoological Journal of the Linnean Society, 155:867-884. doi: 10.1111/j.1096-3642.2008.00471.x

Hardenbol, J.; Thierry J.; Farley M.B.; Jacquin T.; de Graciansky P.-C. \& Vail, P.R. 1998. Mesozoic and Cenozoic sequence chronostratigraphic framework of European basins. Jurassic sequence chronostratigraphy. In: P.C.de. Graciansky; J. Hardenbol; T. Jacquin, \& P.R. Vail (eds.) Mesozoic and Cenozoic sequence stratigraphy of European Basins. SEPM, Special Publication, 60:3-13.

Hershkovitz, P. 1982. The staggered marsupial lower third incisor (I3). Géobios, Mémoire Special, 6:191-200.

Hershkovitz, P. 1995. The staggered marsupial lower incisor: hallmark of cohort Didelphimorphia, and description of a new genus and species with $\mathrm{i} 3$ from the Albian (Lower Cretaceous) of Texas. Bonner Zoologische Beiträge, 45(3/4):153-169.

Horovitz, I.; Martin, T.; Bloch, J.; Ladevèze, S.; Kurz, C. \& Sánchez-Villagra, M. 2009. Cranial anatomy of the earliest marsupials and the origin of opossums. PLOS ONE, 4(12): e8278. doi:10.1371/journal.pone.0008278

Horovitz, I.; Ladèveze, S.; Argot, C.; Macrini, T.E.; Martin, T.; Hooker, J.J.; Kurz, C.; Muizon, C. de \& Sánchez-Villagra, M.R. 2008. The anatomy of Herpetotherium cf. fugax Cope, 1873, a metatherian from the Oligocene of North America. Palaeontographica Abteilung A, 284:109-141.

Johanson, Z. 1996. Revison of the late Cretaceous North American marsupial genus Alphadon. Palaeontographica Abteilung A, 242:127-184.

Korth, W.W. 1994. Middle Tertiary marsupials (Mammalia) from North America. Journal of Paleontology, 68:376-96.

Ladevèze, S. 2004. Metatherian petrosals from the Late Paleocene of Itaboraí (Brazil), and their phylogenetic implications. Journal of Vertebrate Paleontology, 24:202-213.

Ladevèze, S. 2007. Petrosal bones of metatherian mammals from the Late Paleocene of Itaboraí (Brazil), and a cladistic analysis of petrosal features in metatherians. Zoological Journal of the Linnean Society, 150:85-115. doi: 10.1111/j.1096-3642.2007.00282.x

Ladevèze, S. \& Muizon, C. de. 2010. Evidence of early evolution of Australidelphia (Metatheria, Mammalia) in South America: phylogenetic relationships of the metatherians from the Late
Palaeocene of Itaboraí (Brazil) based on teeth and petrosal bones. Zoological Journal of the Linnean Society, 159:746-784. doi: 10.1111/j.1096-3642.2009.00577.x

Legarreta, L. \& Uliana, M.A. 1994. Asociaciones de fósiles y hiatos en el Supracretácico- Neógeno de Patagonia: una perspectiva estratigráfico-secuencial. Ameghiniana, 31(3): 257-281.

Lima, M.R. \& Souza-Cunha, F.L. 1986. Análise palinológica de um nível linhítico da Bacia de São José de Itaboraí, Terciário do Estado do Rio de Janeiro, Brasil. Anais da Academia Brasileira de Ciências, 58:579-588.

Lucas, P.W. 2004. Dental functional morphology. How teeth work. Cambridge, Cambridge University Press, 372 p.

Maas, M.C.; Thewissen, J.G.M. \& Kappelman, J. 1998. Hypsamasia seni (Mammalia: Embrithopoda) and other mammals from the Eocene Kartal Formation of Turkey. Bulletin of Carnegie Museum of Natural History, 34:286-297.

Macedo, A.C.M. 1975. Microfósseis de uma fácies clástico-química da bacia calcária de São José de Itaboraí, RJ. Anais da Academia Brasileira de Ciências, 47(3/4):578.

Marshall, L.G. 1981. Review of the Hathlyacyninae, an extinct subfamily of South American "dog-like" marsupials. Fieldiana Geology, 7:1-120.

Marshall, L.G. 1982a. Systematics of the extinct South American marsupial Family Polydolopidae. Fieldiana Geology, 12:1-109.

Marshall, L.G. 1982b. A new genus of Caroloameghiininae (Marsupialia: Didelphoidea: Didelphidae) from the Paleocene of Brazil. Journal of Mammalogy, 63:709-716.

Marshall, L.G. 1984. The lower jaw of Eobrasilia coutoi Simpson, 1947, a unique didelphoid (not borhyaenoid) marsupial from the Paleocene of Brazil. Journal of Paleontology, 58:173-177.

Marshall, L.G. 1985. Geochronology and land-mammal biochronology of the Transamerican faunal interchange. In: F.G. Stehli, \& S.D. Webb (eds.) The Great American Biotic Interchange, New York, Plenum Press, p. 49-85.

Marshall, L.G. 1987. Systematics of Itaboraian (Middle Paleocene) age "opossum-like" marsupials from the limestone quarry at São José de Itaboraí, Brazil. In: M. Archer (ed.) Possums and Opossums: Studies in Evolution. Surrey Beatty \& Sons and the Royal Zoological Society of New South Wales, p. 91-160.

Marshall, L.G. \& Muizon, C. de 1984. A new didelphid marsupial (Itaboraian) of São José de Itaboraí (Brazil). Comptes rendus de l'Académie des Sciences de Paris, 299(18): 1297-300.

Marshall, L.G.; Case, J. \& Woodburne, M.O. 1990. Phylogenetic relationships of the families of marsupials. In: H.H. Genoways (ed.) Current Mammalogy, Plenum Press, v. 2, p. 433-505.

Marshall, L.G.; Sempere, T. \& Butler, R.F. 1997. Chronostratigraphy of the Mammal-Bearing Paleocene of South America. Journal of South American Earth Sciences, 10(1):49-70.

Marshall, L.G.; Butler, R.F.; Drake, R.E. \& Curtis, G.H. 1981. Calibration of the beginning of the Age of Mammals in Patagonia. Science, 212:43-45.

Martin, J.E.; Case, J.A.; Jagt, J.W.M.; Schulp, A.S. \& Mulder, E.W.A. 2005. A new European marsupial indicates a late Cretaceous high-latitude transatlantic dispersal route. Journal of Mammalian Evolution, 12(3/4):495-511. doi:10.1007/ s10914-005-7330-x

MacPhee, R.D.E. \& Reguero, M. 2010. Reinterpretation of a Middle Eocene Record of Tardigrada (Pilosa, Xenarthra, Mammalia) from La Meseta Formation, Seymour Island, West Antarctica. American Museum Novitates, 3689:1-21. doi:10.1206/703.1 
McKenna, M.C. \& Bell, S.K. 1997. Classification of mammals above the species level. New York, Columbia University Press, $631 \mathrm{p}$.

Medeiros, R.A. \& Bergqvist, L.P. 1999. Paleocene of the São José de Itaboraí Basin, Rio de Janeiro, Brazil: lithostratigraphy and biostratigraphy. Acta Geologica Leopoldensia, 22(48):3-22.

Milani, E.J.; Rangel, H.D.; Bueno, G.V.; Stica, J.M.; Winter, W.R.; Caixeta, J.M. \& Neto, O.C.P. 2007. Brazilian sedimentary basins - stratigraphic charts. Boletim de Geociências da Petrobras, 15(2):183-205.

Mizusaki, A.M.P. \& Mohriak W.U. 1992. Sequências vulcanosedimentares na região da Plataforma Continental de Cabo Frio, RJ. In: CONGRESSO BRASILEIRO DE GEOLOGIA, 37, 1992. Anais, São Paulo, SBG, 2:468-469.

Mizusaki A.M.P.; Alves, D.B. \& Conceição J.C.J. 1994. Eventos magmáticos nas bacias do Espírito Santo, Mucuri e Cumuruxatiba. In: CONGRESSO BRASILEIRO DE GEOLOGIA, 38, 1994. Anais, Camboriú, SBG, p. 566-568.

Mizusaki, A.M.P.; Thomaz Filho, A. \& Césero, P. de 1998. Ages of the magmatism and the opening of the South Atlantic Ocean. Pesquisas em Geociências, 25(2):47-57.

Mizusaki, A.M.P.; Thomaz-Filho A.; Milani E.J. \& Césero P. de 2002. Mesozoic and Cenozoic igneous activity and its tectonic control in Northeastern Brazil. Journal of South American Earth Sciences, 15:183-198.

Muizon, C. de 1991. La fauna de mamíferos de Tiupampa (Paleoceno Inferior, Formación Santa Lucia), Bolivia. Revista Técnica de Yacimientos Petrolíferos Fiscales Bolivianos, 12(3-4):575-624.

Muizon, C. de \& Brito, I.M. 1993. Le bassin calcaire de São José de Itaboraí (Rio de Janeiro, Brésil): ses relations fauniques avec le site de Tiupampa (Cochabamba, Bolivie). Annales de Paléontologie, 79(3):233-269.

Oliveira, E.V. 1998. Taxonomia, filogenia e paleobiogeografia de marsupiais "poliprotodontes" do Mesopaleoceno da Bacia de Itaboraí, Rio de Janeiro, Brasil. Programa de pós-graduação em Geociências, Universidade Federal do Rio Grande do Sul, Tese de Doutorado, 327 p.

Oliveira, E.V. 1999. Systematics of Itaboraian (Medial Paleocene) age "opossum like" marsupials from the Itaboraí Basin, Rio de Janeiro, Brazil. Anais da Academia Brasileira de Ciências, 71:811-812.

Oliveira, E.V. \& Goin, F.J. 1999. Robertbutleria Marshall 1987: un probable sinónimo de Protodidelphis Paula Couto 1952 (Marsupialia, Didelphimorphia, Protodidelphidae). Ameghiniana, 36:17R-18R.

Oliveira, E.V. \& Goin, F.J. 2006. Marsupiais do início do Terciário do Brasil: origem, irradiação e história biogeográfica. In: N.C. Cáceres \& E.L.A. Monteiro-Filho (eds.) Os Marsupiais do Brasil, Universidade Federal de Santa Maria, p. 608-649.

Paula Couto, C.de. 1952a. Fossil mammals from the begining of the Cenozoic in Brazil. Marsupialia: Polydolopidae and Borhyaenidae. American Museum Novitates, 1559:1-27.

Paula Couto, C. de 1952b. Fossil mammals from the beginning of the Cenozoic in Brazil. Marsupialia: Didelphidae. American Museum Novitates, 1567:1-26.

Paula Couto, C. de 1952c. A new name for Mirandaia ribeiroi Paula Couto, 1952. Journal of Mammalogy, 33:503.

Paula Couto, C. de 1961. Marsupiais fósseis do Paleoceno do Brasil. Anais da Academia Brasileira de Ciências, 33(3-4):321333.
Paula Couto, C. de 1962. Didelfídeos fósiles del Paleoceno de Brasil. Revista del Museo Argentino de Ciencias Naturales “Bernardino Rivadavia”, 112:135-66.

Paula Couto, C. de 1970. News on the fossil marsupials from the Riochican of Brazil. Anais da Academia Brasileira de Ciências, 42(1):19-34.

Paula Couto, C. de 1979. Tratado de Paleomastozoologia. Rio de Janeiro, Academia Brasileira de Ciências, 590 p.

Pascual, R. \& Ortiz-Jaureguizar, E. 1991. El Ciclo faunístico Cochabambiano (Paleoceno temprano): su incidencia en la historia biogeográfica de los mamíferos sudamericanos. Revista Técnica de Yacimientos Petrolíferos Fiscales Bolivianos, 12:559574.

Price, L.Y \& Paula Couto, C. de 1946. Vertebrados fósseis do Eoceno Inferior de Itaboraí. Rio de Janeiro, Departamento Nacional da Produção Mineral, Divisão de Geologia e Mineralogia, 3 p. (Notas Preliminares e Estudos 31).

Reig, O.; Kirsch, J.A. \& Marshall, L.G. 1987. Systematic relationships of the living and Neocenozoic American "Opossum-like" marsupials (Suborder Didelphimorphia), with comments on the classification of these and of the Cretaceous and Paleogene New World and European metatherians. In: M. Archer (ed.) Possums and Opossums: Studies in Evolution, Royal Zoological Society of New South Wales, p. 1-89.

Riccomini, C. 1989. O Rift Continental do Sudeste do Brasil. Programa de Pós-Graduação em Geociências, Universidade de São Paulo, Tese de Doutorado, 256 p.

Riccomini, C. \& Rodrigues-Francisco, B.H. 1992. Idade potássioargônio do derrame de ankaramito da Bacia de Itaboraí, Rio de Janeiro, Brasil: implicações tectônicas. In: CONGRESSO BRASILEIRO DE GEOLOGIA, 37, 1992. Boletim de Resumos, São Paulo, SBG, v. 2, p. 469-470.

Riccomini, C.; Coimbra, A.M.; Sant'Anna, L.G.; Brandt Neto, M. \& Valarelli, J.V. 1996. Argilominerais do paleolago Tremembé e sistemas deposicionais relacionados (Paleógeno, Rift Continental do Sudeste do Brasil). Revista Brasileira de Geociências, 26:167-180.

Ride, W.D.L. 1964. A review of Australian fossil marsupials. Journal of the Royal Society of Western Australia, 47(4):97-131.

Rougier, G.W.; Wible, J.R. \& Novacek, M.J. 1998. Implications of Deltatheridium specimens for early marsupial history. Nature, 396:459-463.

Sánchez-Villagra, M.R.; Ladevèze, S.; Horovitz. I.; Argot, C.; Hooker, J.J. ; Macrini, T.; Martin, T.; Moore-Fay, S.; Muizon, C. de; Schmelzle, T. \& Asher, R.J. 2007. Exceptionally preserved North American Paleogene metatherians: adaptation and discovery of a major gap in the opossum fossil record. Proceedings of the Royal Society, Biology Letters, 3:318-322.

Sant'Anna, L.G., 1999. Geologia, mineralogia e gênese das esmectitas dos depósitos paleogênicos do Rift Continental do Sudeste do Brasil. Programa de Pós-graduação em Geociências, Universidade de São Paulo, Tese de Doutorado, 291 p.

Sigé, B.; Archer, M.; Crochet, J.Y.; Godthep, H.; Hand, S. \& Beck, R. 2009. Chulpasia and Thylacotinga, late Paleocene-earliest Eocene trans-Antarctic Gondwanan bunodont marsupials: new data from Australia. Geobios, 42:813-823. doi:10.1016/ j.geobios.2009.08.001

Simpson, G.G. 1935. Occurrence and relationships of Rio Chico fauna of Patagonia. American Museum Novitates, 818:1-21.

Simpson, G.G. 1945. The principles of the classification and a 
classification of mammals. Bulletin of the American Museum of Natural History, 85:1-350.

Simpson, G.G. 1947. A new Eocene marsupial from Brazil. American Museum Novitates, 1357:1-7.

Swofford, D.L. 2003. PAUP*: Phylogenetic Analysis Using Parsimony (* and Other Methods). Version 4. Sunderland, Sinauer Associates.

Szalay, F.S. 1982. A new appraisal of marsupial phylogeny and classification. In: M. Archer (ed.) Carnivorous Marsupials, Royal Zoological Society of New South Wales, p. 621-640.

Szalay, F.S. 1994. Evolutionary history of the Marsupialia and an analysis of osteological characters. New York, Cambridge University Press, 455 p.

Szalay, F.S. \& Sargis, E.J. 2001. Model-based analysis of postcranial osteology of marsupials from the Palaeocene of Itaboraí (Brazil) and the phylogenetics and biogeography of Metatheria. Geodiversitas, 23(2):139-302.

Takahashi, F. 1974. Variação morfológica de incisivos em didelfídeos (Marsupialia, Didelphinae). Anais da Academia Brasileira de Ciências, 46(3-4):413-416.

Tejedor, M.F.; Goin, F.J.; Gelfo, J.N.; López, G.; Bond, M.; Carlini, A.A.; Scillato-Yané, G.J.; Woodburne, M.O.; Chornogubsky, L.; Aragón, E.; Reguero, M.A.; Czaplewski, N.J.; Vincon, S.; Martin, G.M. \& Ciancio, M.R. 2009. New early Eocene mammalian fauna from western Patagonia, Argentina. American Museum Novitates, 3638:1-43. doi: 10.1206/577.1

Thomaz-Filho A.; Cesero, P. de; A.M.P. Mizusaki \& Leão, J.G. 2005. Hot spot volcanic tracks and their implications for South American plate motion, Campos Basin (Rio de Janeiro State), Brazil. Journal of South American Earth Sciences, 18(3-4):383389. doi:10.1016/j.jsames.2004.11.006

Tibana, P.; Castro, J.C., \& Barrocas, S.L.S. 1984. Bacia de Itaboraí. In: CONGRESSO BRASILEIRO DE GEOLOGIA, 33, 1984. Anais, Rio de Janeiro, SBG, v. 12, p. 5309-5316.

Voss, R.S. \& Jansa, S.A. 2009. Phylogenetic relationships and classification of didelphid marsupials, an extant radiation of New World Metatherian mammals. Bulletin of the American Museum of Natural History, 322:1-177. doi: 10.1206/322.1

Woodburne, M.O. \& Case, J.A. 1996. Dispersal, vicariance and the late Cretaceous to early Tertiary land mammal biogeography from South America to Australia. Journal of Mammalian Evolution, 3:121-61.

Wroe, S.; Ebach, M.; Ahyong, S.; Muizon, C. de \& Muirhead, J. 2000. Cladistic analysis of dasyuromorphian (Marsupialia) phylogeny using cranial and dental characters. Journal of Mammalogy, 81:1008-1024.

Received in August, 2010; accepted in April, 2011.

Appendix 1. Taxonomic list of metatherian mammals from Itaboraí, Brazil. Taxa marked in bold are those studied in this work. "Ameridelphia" is not regarded as a natural group.

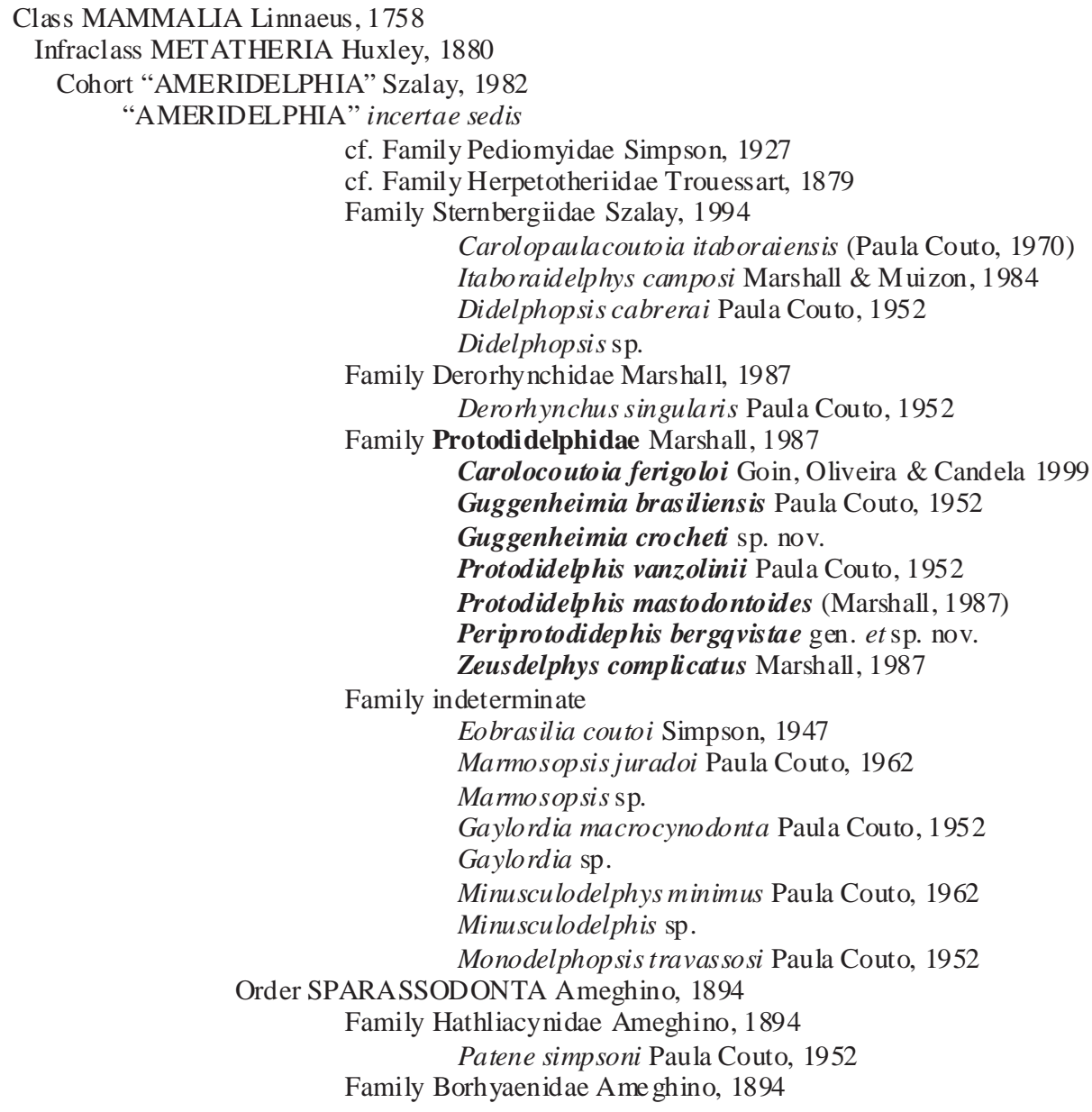




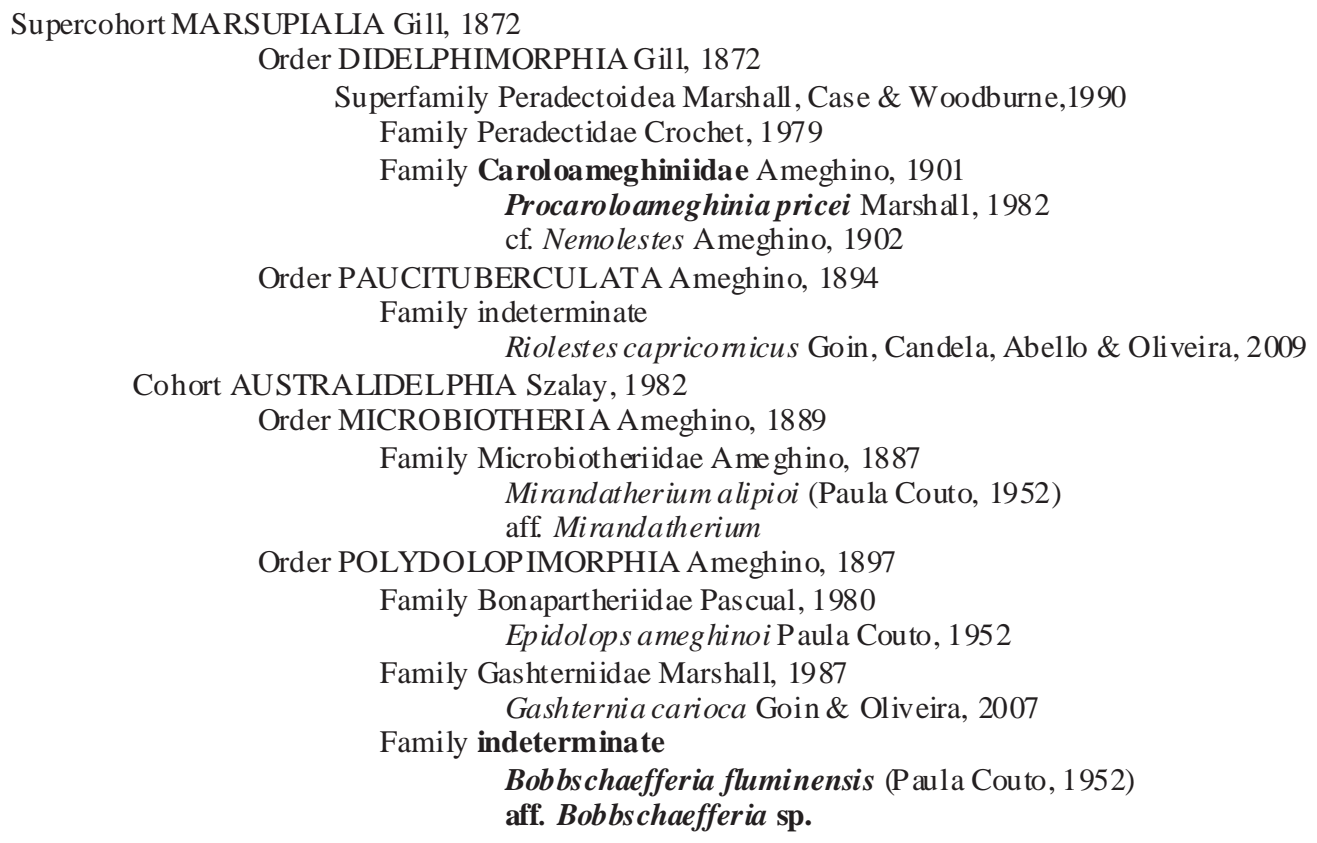

Appendix 2. Characters and character-states.

Character 14 is from Archer (1976); Characters 4, 17, and 20 are from Davis (2007); character 25, 29, 31, 45 are from Johanson (1996); characters 3, 9, 12, 37, 38, 41, 60, 62, 66, 68, and 74 are from Cifelli (1993); characters 27, 44 are from Rougier et al. (1998); character 69 is from Reig et al. (1987); characters 5, 6, 7, 12, 18, 19, 21, 26, 28, 34, 36, 39, 42, 46, 48-58, and 62-67 are from Goin et al. (2006); characters 30, 40, and 43 are from Goin et al. (1998a); characters 32, 70, 71 are from Marshall (1987); character 73 is from Hershokovitz (1995). Characters 1, 2, 4, 10, 11, 13, 15, 23, 24, 33, 35, 59, and 61 are from our determinations, although commented upon by various authors for diverse taxa.

1. Bunodonty (inflated cusps), degree of development: (0) absent, (1) low, (2) high.

2. Crown: (0) high, (1) low, (2) very low.

3. Crests/cristids: (0) shap, (1) moderately sharp, (2) rounded.

4. Ectoflexus. Depth on M2-3: (0) very deep, mainly in M3; (1) moderately deep, mainly in M3; (2) shallow.

5. Stylar cusps. Development of cusps: (0) only styles A and B most developed, (1) A, B, C and D most developed, (2) styles greatly reduced, (3) only B and D most developed.

6. Stylar cusp A: (0) present, (1) enlarged, (2) reduced or lost.

7. StB. Size in relation to the paracone: (0) moderately smaller, (1) reduced, (2) subequal to larger.

8. StB and StD. Position in relation to each other: (0) separated, (1) close to each other.

9. StC development: (0) C is not yet developed, inconsistent or weak, (1) C is consistently present, (2) C reduced or lost.

10. StC subdivided: (0) absent, (1) present.

11. StC. Position relative to StB and StD: (0) not present, (1) positioned between $\mathrm{StB}$ and $\mathrm{StD}$, (2) positioned close to StB, (3) positioned close to $\mathrm{StD}$.

12. $\mathrm{StD}$. Size: (0) poor developed, (1) moderate, (2) large.

13. $\mathrm{StD}$ size relative to metacone: (0) very smaller, (1) smaller, (2) subequal to larger.

14. Access or $y$ stylar cusp (central cusp at the apex of the centrocrista): (0) absent, (1) present.

15. Supernumerary cuspules on the stylar shelf: (0) absent, (1) present . 
Appendix 2. (Cont.)

16. Centrocrista. Mophology in occlusal view: (0) linear, (1) v-shaped poor invasive, (2) v-shaped very invasive, (3) open.

17. Centrocrista : Strength: (0) weakly developed, (1) moderate, (2) strongly developed.

18. Stylar shelf. Width in relation to talon (in M2-M3): (0) wide, (1) narrow to moderate, (2) narrower.

19. Stylar shelf height to trig on basin: (0) about equal heigth, (1) moderately higher, (2) much higher.

20. Conules. Internal conular cristae: (0) present, (1) reduced or absent.

21. Metaconule. (0) well-developed, (1) small, (2) vestigial or absent, (3) hypocone-like.

22. Metaconule. Position: (0) close to metacone, (1) lingually displaced.

23. Metaconule. Morphology: (0) cuspate, (1) not cuspate (included in the trigon).

24. Paracone. Position on relation to StB in M1-2: (0) set apart, (1) close, (2) twinned (almost fused).

25. Paracone and metacone. Shape of labial faces: (0) rounded, (1) flat to concave.

26. Metacone. Size in relation to paracone: (0) subequal to slightly smaller, (1) larger, (2) much larger.

27. Metacone. Position of its lingual face in relation to that of the paracone in M2 or M3: (0) aligned to slightly lingual, (1) clearly lingual to the paracone.

28. Metacone. Position in relation to paracone: (0) separated, (1) appressed.

29. Protocone. Anteroposterior development: (0) narrow, (1) wide.

30. Protocone. Position in M1 or M2 in relation to trans verse mid-line of tooth: (0) central, (1) eccentric.

31. Trigon basin. Depth: (0) deep, (1) shallow.

32. Preprotoconal cingulum: (0) absent, (1) present.

33. Preparacrista. Aspect in occlusal view: (0) straight to arch shaped, (1) curved.

34. Preparacrista. Orientation in relation to stylar cusps: (0) pointed at, or connected with, StB, (1) pointed at, or connected to StA,

(2) reduced or lost.

35. Postmetacrista. Size in relation to preparacrista: (0) about equal, (1) moderately longer, (2) much longer.

36. Postmetacrista. Orientation in relation to transversal axis tooth, mainly in M2 or M3: (0) poor oblique, (1) very oblique.

37. Preprotocrista. Morphology: (0) extends labially past paracone (double rank prevallum/postvallid shear, (1) no extension past paracone.

38. Postprotocrista: (0) postvallum-prevallid shear emphasized, (1) extends labially past metacone (double rank postvallum/prevallid shear), (2) no extension past metacone, (3) shear de-emphasized by development of hypocone.

39. Angle between pre- \& postprotocristae: (0) acute angle, (1) right angle, (2) obtuse angle.

40. Zigzag crest linking StB and StD: (0) absent, (1) present.

41. Postvallum/prevallid shear. (0) strong, with paraconid large, (1) modestly developed, metaconid reduced; salient postmetacrista,

(2) reduced (bunodonty), (3) supplanted by quadrituberculy.

42. Prevallum/postvallid shear. (0) strong; paraconid and metaconid large, preparacrista deeply notched, stylar shelf raised, (1) developed, (2) reduced (bunodonty), (3) supplanted by quadrituberculy.

43. M1/m1-M3/m3. Size from M1 to M3: (0) abrupt increase in size, (1) gradual increase in size, (2) gradual decreasing size.

44. M4/m4. Size in relation to M3: (0) subequal to slightly smaller, (1) moderately smaller, (2) quite smaller.

45. Posterior cingulum (postmetacingulum). Development: (0) reduced, (1) well-developed, (2) absent.

46. Anterior cingulum. Trajectory: (0) wide and connects preprotocrista, (1) narrow and connects preprotocrista, (2) reduced to labial half of the paracone.

47. Upper molar morphology. Outline in occlusal view: (0) subtriangular, (1) subquadrangular. 
Appendix 2. (Cont.)

48. Protoconid size: (0) larger than the metaconid, (1) subequal with the metaconid in height.

49. Protoconid position: (0) anterior to the metaconid, (1) about opposite to the metaconid, (2) well posterior to the metaconid.

50. Talonid length vs trigonid length: (0) subequal in length, (1) talonid longer than the trigonid, (2) talonid shorter than the trig onid.

51. Trigonid. Relative width of the trigonid versus the talonid: (0) wider than the talonid, (1) about equal to the talonid, (2) narrower than the talonid.

52. Trigonid height ( $\mathrm{m} 3$ or $\mathrm{m} 2$ if $\mathrm{m} 3$ is not present) versus the talonid: (0) twice the height of the talonid, (1) lower height.

53. Metaconid. Transversal position in relation to protoconid: (0) posterior, (1) at the same level to slightly posterior, (2) anterior.

54. Entoconid shape: (0) conical, (1) bladed, flattened labiolingually, (2) reduced, (3) massive, occupying much of the talonid.

55. Entoconid position: (0) located at the posterolingual corner of tooth, (1) located more anteriorly, with the hypoconulid at the posterolingual corner of tooth.

56. Paraconid size. (0) about equal to the metaconid, (1) smaller than the metaconid, (2) minute to absent.

57. Paraconid position: (0) lingually placed, (1) anteromedially located, (2) paraconid appres sed to metaconid.

58. Trigonid pre- \& postprotocristid angle: (0) forms acute angle, (1) about equilateral, (2) forms obtuse angle.

59. Paraconid. Degree of anteroposterior compression: (0) not compressed, (1) compressed.

60. Cristid oblique attachment: (0) below the notch in the postprotocristid (=carnassial notch), (1) between the notch and the labial base of the protoconid, (2) labially, at the base of the protoconid, (3) Absent.

61. Cristid Oblique. Shape: (0) rectilinear, (1) sinous.

62. Hypoconulid position: (0) terminal in position, not twinned with the entoconid, (1) more lingually placed, still nearly terminal and twinned with the entoconid, (2) lingual in position and twinned with the entoconid, (3) posterolingual in position, not twinned with the entoconid.

63. Hypoconulid-entoconid size: (0) entoconid>hypoconulid, (1) entoconid >>hypoconulid, (2) hypoconulid very reduced or absent, (3) hypoconulid equal to larger than entoconid.

64. Hypoconid-entoconid size: (0) hypoconid>entoconid, (1) hypoconid=entoconid, (2) Hypoconid<entoconid.

65. Hypoconid-entoconid position: (0) hypoconid anterior to the entoconid, (1) hypoconid opposite of the entoconid, (2) hypoconid posterior to the entoconid.

66. Hypoconid morphology: (0) labial face gently rounded, (1) labial face sharply angular, (2) labial face expanded.

67. Posthypocristid: (0) short, extends only to the midline of the tooth, (1) extends farther lingually.

68. Labial postcingulid: (0) present, (1) lacking.

69. Lower premolars. p2 and p3 relative sizes: (0) p3 longer than P/p2, (1) p3 subequal to shorter than P/p2.

70. Lower premolars. Outline of P3: (0) ovoid, (1) labiolingually compressed, (2) subtriangular.

71. Lower premolars. p1. Location in relation to dentary axis: (0) aligned; (1) oblique.

72. Lower premolars. Sectorial p3: (0) absent, (1) present.

73. Lower incisors. Staggered incisor: (0) absent, (1) present.

74. Size (judging from dentition). (0) small (Micoures to Calorumys size; maximum dimensions <3mm, (1) large sized (Phylander/Didelphis-like); maximum dimensions $>3 \mathrm{~mm}$, (2) minute sized. 
Appendix 3. Character matrix.

11111111112222222222333333333344444444445555555555666666666677777

Taxon/Node

Kokopellia

Microbiotherium

Mirandatherium

Kashia

Patene

Procaroloameg hinia

Djarthia

Peratherium

Carolopaulacoutoia

Itaboraidelphys

Didelphopsis

Minusculodelphis

Monodelphopsis

Tiulordia

Gaylordia

Marmosopsis

Szalinia

Pucadelphys

Derorhynchus

Protodidelphis

Carolocoutoia

Zeusdelphys

Gugenheimia

Periprotodidel

Philander

Caluromys

Epidolops

Roberthoffstetteria

Bobbschaefferia

Gashternia 12345678901234567890123456789012345678901234567890123456789012345678901234 00000000000000000000000000000000000000000000000000000000000000000000000000 1112201-2000-000020-100-000010000111120-1212200000210001010101011101001000 111 ?????????????????????????????????????1?1 ????000210001010101011 $1010010 ? 0$ 1112201-2000-000020-100-000010000111120-121?200000210001010101000101?????0 $001100102000000000000000010100000120110-1101000002200010010101301000 ? 0 ? 0 ? 1$ $211 ? 1220101210000001000001001000012011002211200000210011000102200001 ? 000 ? 0$ $0001100010111102111 ? 0001121000 ? ? 0011 ? ? ? 0111121001010101100010211211100 ? 0 ? 0$ $0001100010211102111100011210000010110210111121001010101100010211211100 ? 010$ $000110001021010211110001121000000011010011112100121010110001021111110000 ? 0$ $0001100011211112111130011210000000010210111121000010101100010210110000 ? 0 ? 1$ $100110001111111211113001121000000001021011112100021010110001021011010000 ? 1$ $000011001011100121211011121100000010020011112100120012111002013000011 ? 00 ? 2$ 000???????????????????????????????????????????0?20012111002013000011000?0 $00111000101110012121101 ? 121100000010020011 ? ? 210012011011201102301001 ? 0 ? 0 ? 0$ $001110001011100121211011121100000010020011112100220020112011123011010000 ? 0$ 00011000101110012121101112100000001102001111220010101011000111301101000010 00001100101110012121101112110000001102001111210012101011000111301001000010 00011100101110012111101112100000001102001111220010001011000101101000000010 $000110001021100211110001121000001011021011112000101010110001021121111 ? 0 ? 10$ 222230212-02200211112--11210111110110201220020000021031100010211101100?0?1 222230212-02200211 112--1 12101?1 $10011020122 ? ? 200 ? ? ? ? ? ? ? ? ? ? ? ? ? ? ? ? ? ? ? ? ? ? ? 1$ 222232212-0220021 1112--112101 100001 1020022??200????????????????????????1 $111 ? 30112-02100211112--1121001010021020022 ? 02000022103110001021110110 ? 0 ? 10$ 221?30202-02200211112--1121010000010120022??20?????????????????????????1 $000112001011100121212--212100000002102001111220010201100000201201201100011$ 01111200101110011111101212101000012102001112220000200100000201201201100010 $111132212-0220030201310200001010-2--132033220011202113022213-3201001021100$ $2121102010322003020131020100101001010120220010110011000011010010001100 ? ? ? 1$ $111110201031100102010101010010000101012022 ? ? 000000110100110100111011001001$ 111132212-0220030201310200001010-2-?130033??001 1202113022213-3201001 ?????0 